\title{
The added-worker effect in the Netherlands before and during the Great Recession
}

\section{Emile Cammeraat $\mathbb{D}^{1} \cdot$ Egbert Jongen $^{2} \cdot$ Pierre Koning $^{3}$}

Received: 30 March 2021 / Accepted: 6 December 2021 / Published online: 3 January 2022

(c) The Author(s), under exclusive licence to Springer Science+Business Media, LLC, part of Springer Nature 2021

\begin{abstract}
We study the added-worker effect in the Netherlands with large-scale administrative panel data for the period 1999-2015. Conditioning on samples with similar employment histories, we employ differences-in-differences to estimate the effect of a male partner's unemployment shock on the female partner's income. We find a modest added-worker effect of $2-5 \%$ of the male partner's income loss, as compared to the much larger compensating effect from social insurance schemes. The addedworker effect largely disappeared at the beginning of the Great Recession, but resurfaced a few years later. Over the years, profits from self-employment have become more important in dealing with unemployment shocks.
\end{abstract}

JEL codes $\mathrm{C} 21 \cdot \mathrm{H} 31 \cdot \mathrm{J} 21$

Keywords Added-worker effect · Great Recession · Differences-in-differences

\section{Introduction}

Faced by the new recession induced by the COVID-19 pandemic, there is increased interest of policymakers and academics in how households deal with the shock of job loss. Income shocks from job loss can partly be mitigated by increases in labour supply of the partner-also known as the 'added-worker effect' (henceforth AWE).

\footnotetext{
Supplementary information The online version contains supplementary material available at https://doi. org/10.1007/s11150-021-09595-2.

Emile Cammeraat

e.cammeraat@cpb.nl

1 CPB Netherlands Bureau for Economic Policy Analysis, Leiden University, The Hague, Netherlands

2 CPB Netherlands Bureau for Economic Policy Analysis, Leiden University and IZA, The Hague, Netherlands

3 Vrije Universiteit Amsterdam, Tinbergen Institute and IZA, Amsterdam, Netherlands
} 
While the empirical literature generally finds the AWE to be small—see, e.g., Hardoy \& Schøne (2014), Bredtmann et al. (2018) and Halla et al. (2020) for recent contributions - a pertaining question is whether its effect varies over the business cycle. With higher unemployment risks and larger earnings shocks during recessions, one might expect the overall impact of the AWE to become more sizable. At the same time, partners may find it harder to find a job or work more hours during an economic downturn. The overall consequences of the business cycle on the AWE are therefore mainly an empirical question.

This paper studies how the AWE has evolved in the Netherlands between 1999 and 2015. For this, we use administrative data of about 1.8 million individuals from the Labour Market Panel (LMP) of Statistics Netherlands. In the period under investigation, changes in the Dutch labour market can be characterized both by substantial changes in the business cycle-the Great Recession in particular-and secular increases in the (part-time) labour supply of women and self-employed workers. We track labour market outcomes and a broad range of income sources that are included in the LMP, including profits from self-employment. We compare the AWE for various cohorts with different labour market conditions and channelled through income from both wage earnings and profit income. Overall, this provides a broad and consistent overview of the substance and mechanisms behind the AWE over a long stretch of time.

Our empirical strategy entails a comparison of women with male partners who became unemployed to women with male partners that remained employed in a given year. The samples consist of female partners with male workers with very similar employment histories. Given that both the treatment and control samples have stable employment positions in the 4 years preceding the possible receipt of UI benefits and job exits are involuntary, we argue it is likely that individuals cannot anticipate or coordinate the onset of UI spells of their partner. This then allows us to follow a differences-in-differences design to estimate the impact of a male partners unemployment shock in a particular year on the earnings of both partners, the employment of the female partner, income from unemployment insurance (UI) and other social benefits and profits from self-employment. All relevant effects are measured over a time window from 4 years before entering UI to 3 years after entering UI. Using different reference years for the unemployment shocks occurring in our sample, we assess how these effects vary with respect to the business cycle.

Since the seminal work of Heckman and MaCurdy (1980), an extensive literature has developed that investigates the size of and mechanisms behind added-worker effects. Supplementary Table A.1 provides an overview of related studies, the data that they use, the empirical methodology and the main findings. Since the turn of the century, we observe a switch from the use of survey data to data from larger administrative panels. A number of recent papers use differences-in-differences estimation, as we do in this paper, often using mass layoffs as an instrumental variable for involuntary job loss (Hardoy \& Schøne, 2014; Halla et al., 2020). The idea here is that firm closures or reorganizations are exploited as plausibly exogenous drivers of job loss and the consecutive AWE. A common finding of these studies is that the AWE - both in terms of employment and wage earnings-is generally small.

Turning to studies with a focus on business cycle effects, the evidence so far does not point at markedly stronger or weaker AWE during times of recessions 
(Bredtmann et al., 2018, Mattingly \& Smith, 2010). Juhn \& Potter (2007) and Bryan \& Longhi (2018) suggest that labour demand effects may offset the effect of increased labour supply of partners. In this context, increased labour supply and increased job search activities are typically inferred from survey data. Halla et al. (2020) find the AWE to be confined to districts with low unemployment rates. Finally, Ayhan (2018), Ghignoni \& Verashchagina (2016) and Parker \& Skoufias (2004) also analyze changes in labour supply of partners in times of recession, but do not provide a causal inference on the AWE. At this point, it is important to stress that most studies focus on limited time periods for inference on the presence of the AWE during a specific economic downturn. This renders it difficult to compare changes in the AWE over the business cycle.

Our main contribution to the literature is that we provide a broad range of AWE estimates measured over a long time period with substantial variation in labour market conditions. This long time period does not only allow us to consistently compare changes in the AWE over the business cycle, but also to uncover changes in the AWE stemming from secular changes in the labour market. On the one hand, the Dutch labour market was characterized by a steep increase in-mostly part-timelabour force participation of women. Hence, compared to other OECD countries, it can be argued that female workers had more room to expand working hours as a response to the job loss of their partner. Of particular interest, therefore, is the distinction between intensive and extensive margin responses of partners. On the other hand, we observe a steadily growing share of self-employed individuals in the Netherlands since 1999. In this setting, we are the first to analyze the importance of intra-household insurance that runs through increased income from self-employment.

The main findings of our analysis can be summarized as follows. First, we find that the unemployment shock of a male partner, causing a loss in the annual gross income of 20-30 thousand euros, on average has a small, positive and statistically significant AWE of 2-5\% (500-1000 euros). This is comparable to the AWE estimates of Juhn \& Potter (2007), Hardoy \& Schøne (2014), Starr (2014), Bredtmann et al. (2018) and Halla et al. (2020). Second, the AWE estimates largely disappeared during the first years of the Great Recession (2008-2009). While this may appear at odds with earlier research in this field-see, e.g., Mattingly \& Smith (2010) and Bredtmann et al. (2018) - it is in line with Halla et al. (2020). Third, the AWE from increased profits from self-employment of the female partner has increased over the years, up to about $2 \%$ (500 euros). Finally, our findings point to both an intensive and an extensive margin AWE. Here we add to the literature that provides mixed evidence on the importance of the intensive and the extensive margin in the AWE-see, e.g., Hardoy \& Schøne (2014), Bredtmann et al. (2018) and Halla et al. (2020). Our results indicate that the decrease in the AWE at the start of the Great Recession is mostly driven by a decrease in the intensive margin effect, i.e., less additional hours worked by partners that were already employed. This points at restrictions from the firm side in recessions.

The outline of the paper is as follows. The section 'Setting' gives background information on the Dutch labour market and the UI system. The section 'Empirical methodology' considers the empirical methodology. The section 'Data' discusses the dataset and gives descriptive statistics. The section 'Estimation results' presents the estimation results. The section 'Discussion and conclusion' discusses our findings and concludes. 


\section{Setting}

Similar to most developed countries, in the Netherlands eligibility to UI applies to involuntary dismissals and for economic reasons, such as firm restructuring or bankruptcies. Applications for UI benefits can be filed either at the offices of the social benefit administration or at offices of sub-district courts. For both dismissal procedures, there are substantial costs due to relatively long waiting times-with continued wage payments - or severance payments. Apart from the formal application requirements, this renders it unattractive for employers to misuse the UI scheme as an (unintended) pathway for voluntary quits of their workers.

The Dutch UI scheme insures all employees against the risk of unemployment. In principle, the scheme replaces $75 \%$ of pre-application wages in the first two months, and $70 \%$ of pre-application wages from 3 months onwards. Until 2006, the maximum entitlement period amounted to 60 months for workers with sufficient work history. Since the 2006 reform, the maximum entitlement period was reduced to 38 months. Below this maximum, each additional year of working history translates into one additional month of UI entitlement. The 2006 reform has restricted the opportunities to use the UI scheme as a stepping stone towards the receipt of pensions.

To provide insight in the labour market context of our study, Fig. 1 compares various labour market characteristics and labour market outcomes of the Netherlands over time and to other countries. Panel a presents the labour force participation rates for women in 2000 and 2015 for 16 developed OECD countries. The Netherlands has experienced one of the fastest increases in the female labour force participation rate over this period, amounting to almost 10 percentage points. As a result, the Netherlands has reached female participation levels that are close to those in Scandinavian countries. ${ }^{1}$ As Bredtmann et al. (2018) argue, higher female labour force participation rates are expected to limit the room for extensive margin added-worker effects. At the same time, panel b suggests that the high share of part-time employment in the Netherlands provides substantial room for women to increase working hours, and hence intensive margin added-worker effects.

Between 2000 and 2015, the Dutch labour market has also seen a marked increase in the share of employees with fixed-term contracts and self-employed. The share of employees on fixed-term contracts increased from around 15\% in 2000 to around $20 \%$ in 2015, which is one of the highest across OECD countries (OECD, 2018). The increase in the share of self-employed in the Netherlands was the largest for OECD countries (OECD, 2018), see also panel c of Fig. 1. Self-employment may also have increasingly been used to mitigate income shocks resulting from job loss (OECD, 2018).

Panels $d$ and e of Fig. 1 portray the impact of business cycle conditions on labour market outcomes in the Netherlands. The unemployment rate of the Netherlands, shown in panel d, denoted by the blue dotted line, was relatively low at the beginning of the twenty-first century. It increased from $3.1 \%$ in 2001 to almost $5.8 \%$ in 2005 , due to the dot-com crisis, after which it decreased again to $3.7 \%$ in 2008 . The increase in the unemployment rate in 2009 was smaller in the Netherlands than in most other OECD countries affected by the Great Recession, but it persisted for a

\footnotetext{
${ }^{1}$ For men, the Netherlands has the third highest labour force participation rate of the OECD in 2015, see Supplementary Fig. A.1.
} 
(a) Labour force participation rates for women

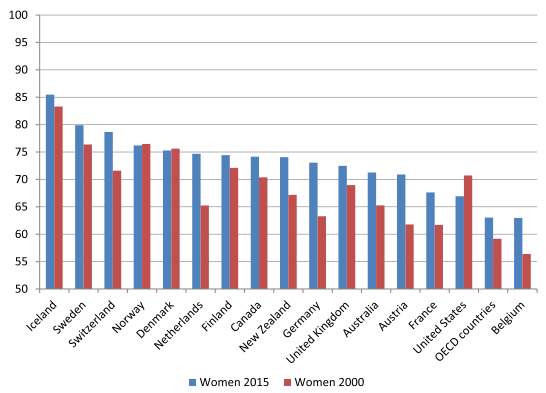

(c) Share of self-employed as a \% of total employed

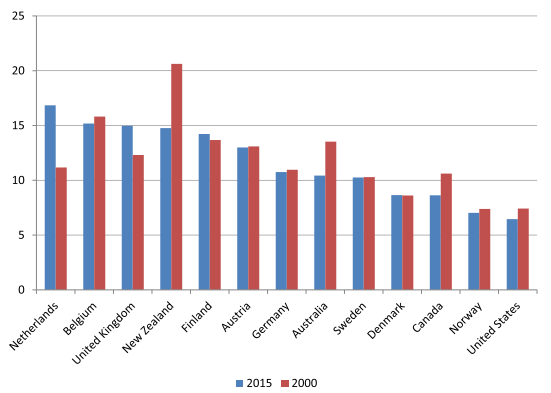

(b) Incidence of part-time employment in 2015



(d) Unemployment rates

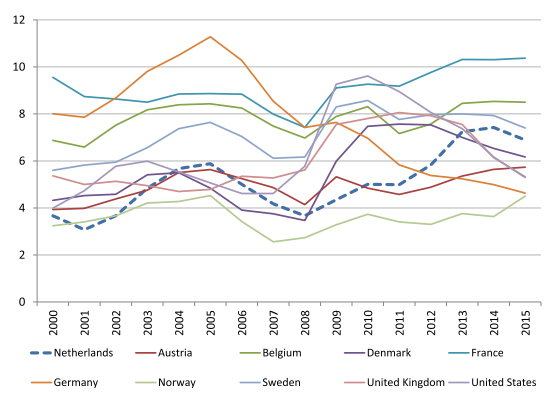

(e) Vacancy-to-unemployment ratio

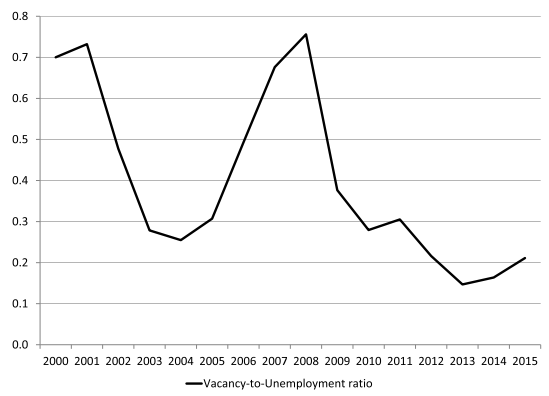

Fig. 1 Dutch labour market indicators

longer period of time and reached a peak of $7.4 \%$ in 2014 . These changes are also visible in panel e, which depicts the vacancy-to-unemployment ratio in the Netherlands between 2000 and 2015.

\section{Empirical methodology}

Similar to earlier studies on the AWE, our analysis essentially builds on two ingredients. First, we need to define plausibly exogenous income shocks that cannot be anticipated by workers' partners. In line with related studies in this field, we use the inflow into 
UI benefits causing a drop in household income. Another set of recent studies uses plant closures and mass layoffs as the exogenous cause of income shocks (Hardoy \& Schøne, 2014; Halla et al., 2020). Since we consider individual income shocks into UI following from involuntary job exits, the initial shock effect on the male worker is probably larger than with plant closures and mass layoffs (compare with, e.g., Hardoy \& Schøne, 2014), many of which transit to another job without an intermittent UI spell.

As a second ingredient, we construct samples of treatment and control groups of workers with similar time effects before the onset of UI spells. This allows for a differences-in-differences design to estimate the effect of income shocks on outcome measures. Specifically, we select couples 25-55 years of age with male partners with an income from work of at least 5000 euros and with no income from UI, social assistance or other social benefits in the four years before becoming unemployed. These selection criteria ensure that the treatment and control groups have similar (stable) labour market positions for a long stretch of time. Accordingly, we do not include workers with temporary contracts in our sample.

Our key assumption needed for the identification of the AWE is that the income shock of the male worker is exogenous from the perspective of the partner. Partners should not be able to anticipate the income loss of the male worker and coordinate labour supply decisions within the household. We argue that such anticipation of the (exact) timing of the firing is unlikely to occur, as UI benefits only apply to involuntary job exits. ${ }^{2}$ Still, it may be that partners are aware that their male partner has a high risk of being fired in the nearby future. If the partner, therefore, increases working hours before the start of the UI spell, we may underestimate the AWE in de DID framework. For this reason, we test for potential anticipation effects with placebo tests in the two years before the actual start of UI spells. ${ }^{3}$

For our estimation model, we define the treatment group as those women with a partner who worked in $t-1$ and started receiving UI benefits in period $t$. The control group consists of women with a partner who did not receive UI benefits in both period $t-1$ and $t$. For each year in our sample, we construct treatment and cohort groups this way. In effect, this means that we have ten cohort years (2003-2012) for which we constructed balanced samples including four years before becoming unemployed, the year of the income shock, and three years thereafter. For these samples, we estimate linear models that are specified as follows:

$$
Y_{i t}=X_{i t}^{\prime} \beta_{x}+\tau_{t}+\alpha_{i}+\sum_{j=-2}^{3} d_{i t}^{j} \gamma_{j}+\epsilon_{i t},
$$

for individual $i$ in year $t$. Our key outcome variable $Y$ is the AWE for partners, but we also consider job loss effects on the labour income of the male worker and other income sources (different types of social insurance). These outcome variables $Y$ are regressed on a set of time-varying demographic controls (age) $X_{i t}$, year fixed effects $\left(\tau_{t}\right)$,

\footnotetext{
${ }^{2}$ It can be argued that in some cases firings may also be of mutual interest to the employer and the worker. This is unlikely to occur in the current context, with substantial income losses that are observed and with workers that are too young to consider UI as a pathway into old-age pensions.

3 Furthermore, workers on temporary contracts who may want to stop working or switch to selfemployment may also enter UI voluntarily by letting their contract expire. Unfortunately, we do not have information on contract type in the dataset.
} 
individual fixed effects $\left(\alpha_{i}\right)$, and the treatment dummies $d_{i t}^{j}$ which are equal to one if the partner of woman $i$ became unemployed in year $t, j$ years from year $t$, and zero otherwise. The term $\epsilon_{i t}$ denotes cluster-robust standard errors at the individual level. ${ }^{4}$

Equation (1) can be estimated with individual fixed effects estimation. ${ }^{5}$ As such, we control for a priori differences in outcomes between the treatment and control groups. Our parameters of interest that describe the AWE are included in vector $\gamma$. For values of $j$ that are zero or positive, $\gamma$ equals the short- and longer-term effects of the unemployment shock. For the two pre-treatment dummies, the values of $j$ are negative and $\gamma$ captures potential anticipation effects or different trends in the two years before the husbands' income shock, hence these are placebo tests.

\section{Data}

We use administrative data from the Labour Market Panel (Arbeidsmarktpanel) of Statistics Netherlands (2015). The Labour Market Panel is a large and rich household panel dataset, tracking 1.8 million individuals over the period 1999-2015. The main outcome variables we consider are female partner's wages and profits from selfemployment, male partner's wages and profits from self-employment, income from UI benefits, social assistance benefits, welfare benefits, disability benefits and other benefits. We also estimate the AWE on the participation rate and on the number of hours worked that are observed in the data. ${ }^{6}$ All variables are measured on an annual basis.

We select couples in which both partners are 25-55 years of age to make the treatment and control group comparable. Younger individuals are often studying or living with their parents, and older individuals are more likely to anticipate old-age benefits in the years before retirement. ${ }^{7} \mathrm{We}$ also restrict the sample to heterosexual couples, who stay together during the full eight years in the balanced samples. ${ }^{8}$

Table 1 presents sample characteristics for our balanced panels consisting of 'treated' individuals and untreated individuals, for selected cohorts (2004, 2008 and 2012). The table shows the values that are averaged over the pre-treatment period, consisting of the four periods before the 'treated' individuals enter UI. Comparing treatment and control group averages, we find relatively small differences in age for both male and female partners. There are however some differences in the averages of the treatment group and control group with respect to ethnicity and the level of education.

\footnotetext{
${ }^{4}$ In the results section, we consider different levels of clustering of the standard error. We consider i.i.d. standard errors, cluster-robust standard errors at the individual level (base specification), cluster-robust standard errors at the level of provinces, and cluster-robust standard errors for provinces interacted with nationality. The statistical significance of the AWE estimates is robust across these different levels of clustering.

5 Note that the group dummy is absorbed by the individual fixed effects.

${ }^{6}$ Unfortunately, data on hours worked is only available for the shorter period 2006-2015.

7 Note that this is particularly relevant before the UI reform of 2006, when the maximum entitlement period was still 5 years.

${ }^{8}$ We do not consider same-sex couples because the distinction between same-sex couples and friends living together is harder to make with the data.
} 


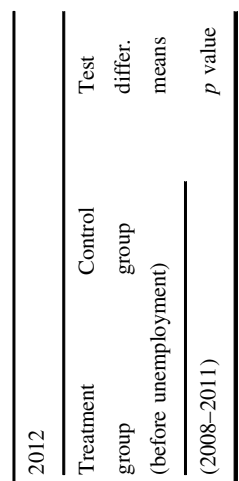

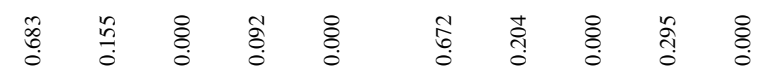

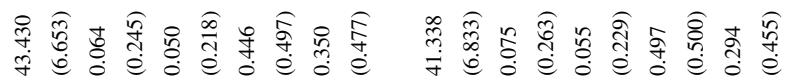

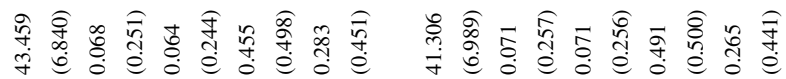

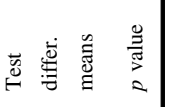

$\begin{array}{llllllllll}0 & 0 & 8 & 0 & 0 & 0 & 0 & 0 & 0 & 0 \\ 0 & 0 & 0 & 0 & 0 & 0 & 0 & 0 & 0 & 0\end{array}$

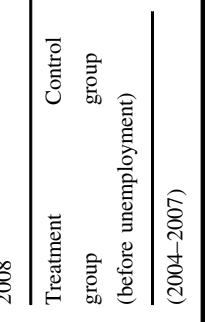

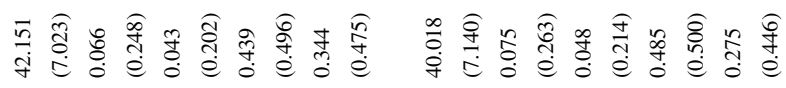

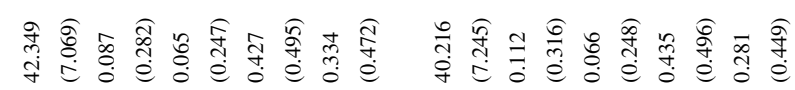

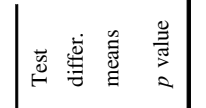

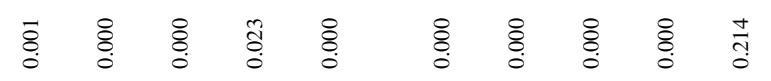

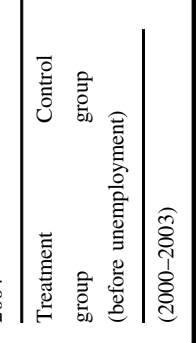

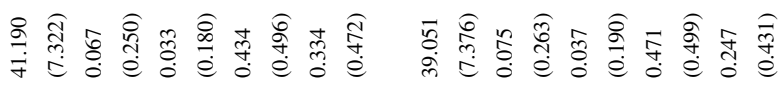

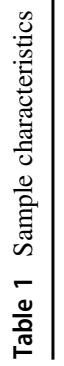

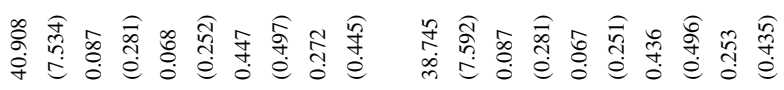

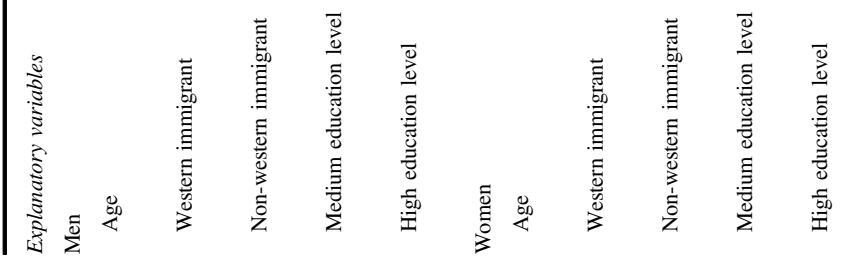




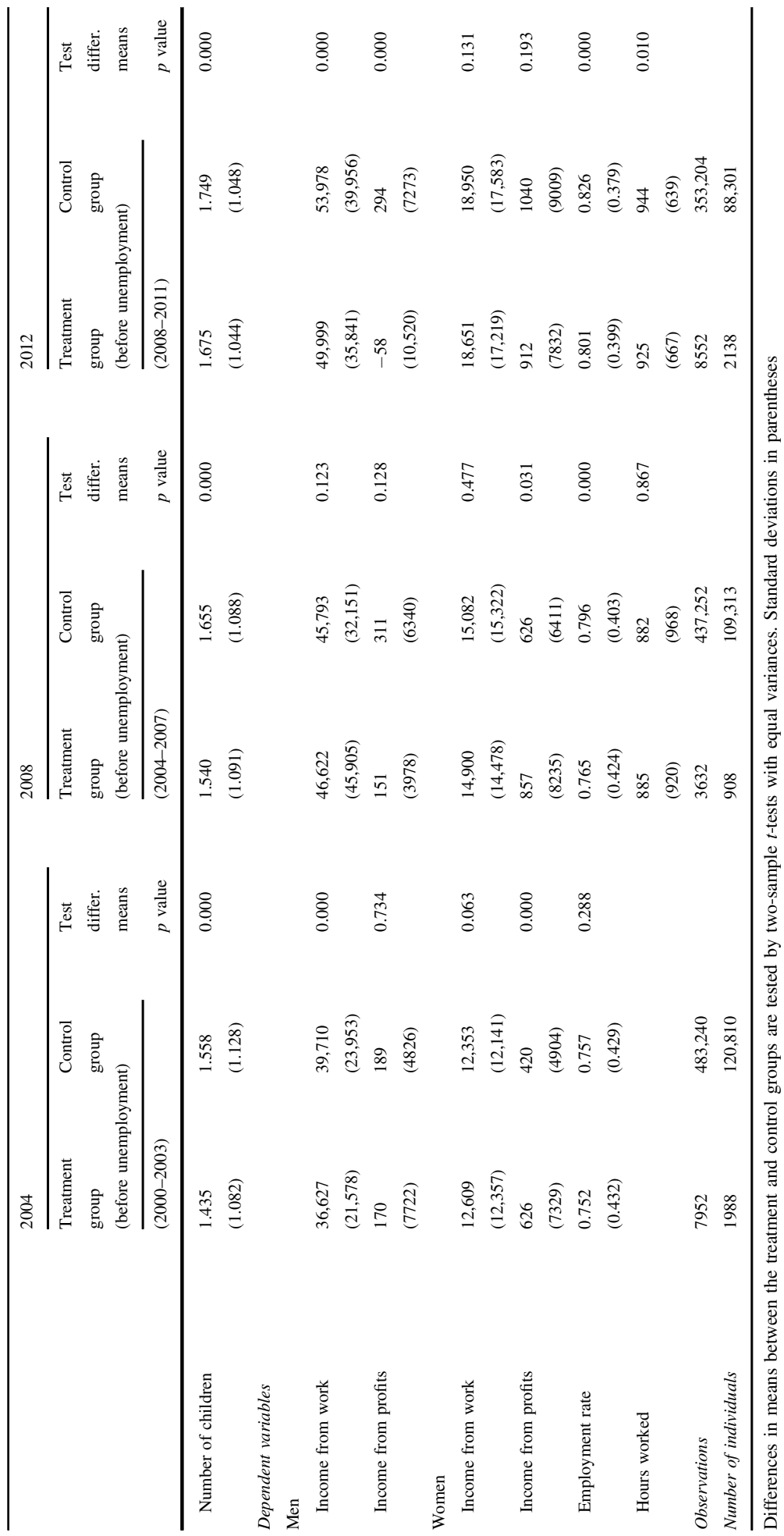


As to the outcome variables of our analysis, we see some differences in earnings in the pre-treatment period for the treatment and control groups. Men in the treatment group earned 3000-4000 euros (about 8\%) less in the treatment group than the control group for the treatment years 2004 and 2012, whereas men who became unemployed in 2008 earned slightly more than the control group. The average male partner's income from profits is slightly smaller in the treatment group than in the control group for the treatment years 2008 and 2012. Female partner's income from work and from profits as well as their employment rates are all about the same for the treatment and control groups for the different treatment years.

While the differences in sample characteristics for the treatment and control group in the pre-treatment period are small for most sample characteristics, some are still statistically significant due to the very large sample size of our dataset. However, these small but statistically significant differences are less of a problem in our difference-in-differences methodology, compared to, e.g., a regression discontinuity design, since the differences-in-differences methodology controls for fixed observed and unobserved differences between the treatment and control group in our balanced sample.

\section{Estimation results}

\subsection{Wage earnings and profits}

For graphical evidence of the presence of the AWE in our data, Fig. 2 shows the average income of female partners from four years before the male partner starts to receive UI benefits until three years thereafter. The solid black lines denote the control group (women whose male partner did not enter UI), the dashed red lines the 'treatment' group (women whose partner did enter UI) and the dotted blue lines the differences between the treatment group and the control group. We see that income from work for both groups generally appears to move parallel before the year the men of the women in the 'treatment group' enter UI, consistent with the assumption of common time effects. ${ }^{9}$ Similar eyeball tests suggest the presence of a small, positive AWE for most reference years.

Table 2 gives the estimated treatment effects on the income of the male partner, i.e., the direct effect of the unemployment shock on the wage income of the male partner. The different columns present the results for different treatment years (years in which male partners enter UI) and the rows show the treatment effect from two years before the treatment $(t-2)$ up to three years after the treatment $(t+3)$. The pretreatment placebo dummies are sometimes statistically significant (note the very large number of observations we use in all regressions), but small compared to the 'treatment' effect from year $t$ onwards. For most treatment years we observe a negative treatment effect on male partner's income of about 15 thousand euros in the year that the male partner enters UI. The effect increases to about 25 thousand euros in the year after (the year) entering UI, which is more than $50 \%$ of the income before

\footnotetext{
9 For 2007, the data hint at some divergence before men enter unemployment insurance. Below, we consider a more formal placebo test of the common time effects assumption.
} 
(a) 2003

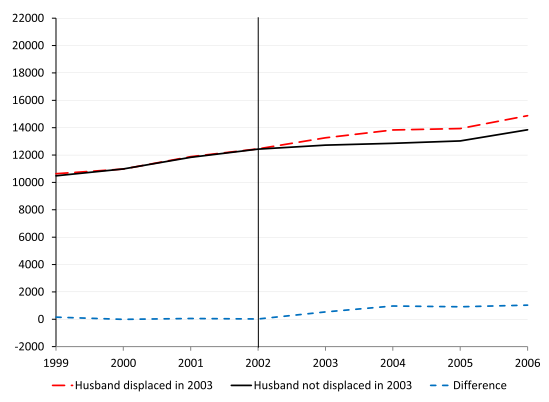

(c) 2005



(e) 2007

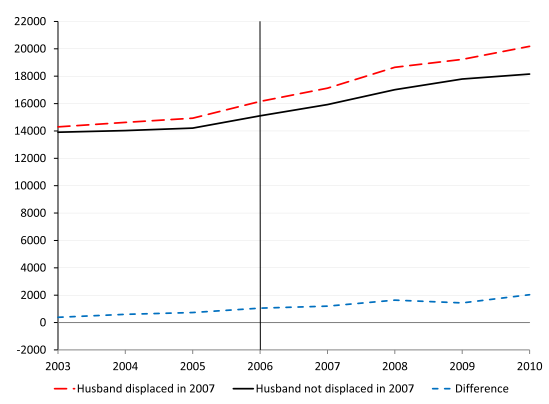

(g) 2009

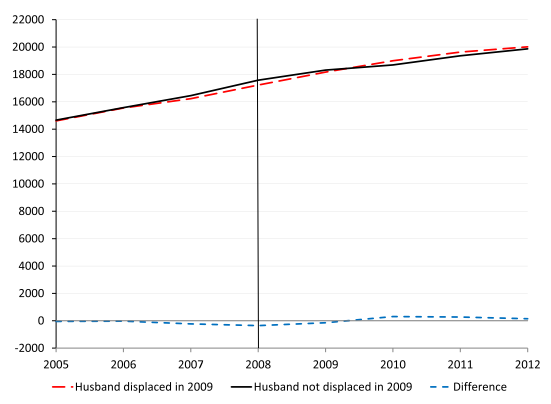

(b) 2004

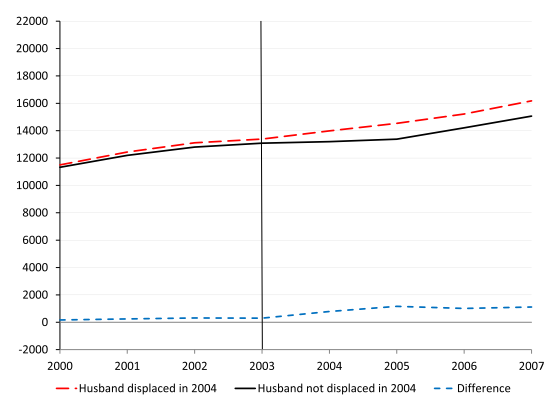

(d) 2006

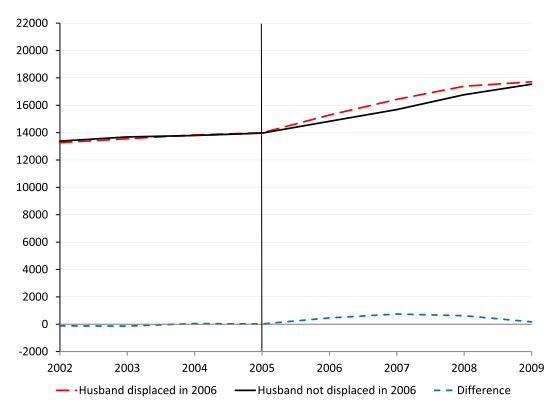

(f) 2008

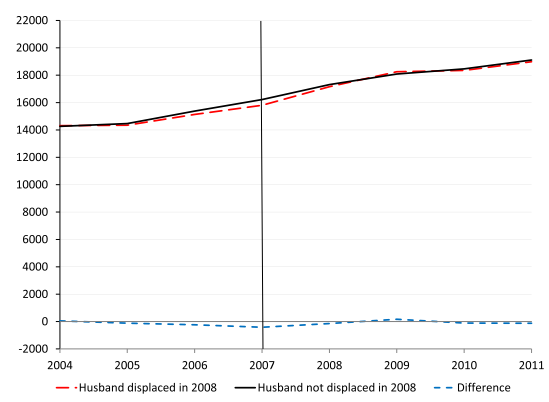

(h) 2010

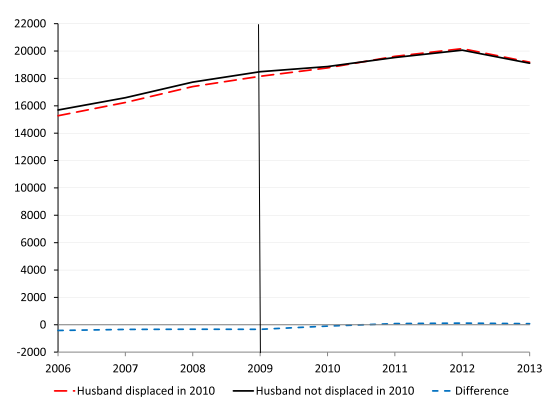

Fig. 2 Wage income for women whose male partner enters UI in a specific year (treatment group) or not (control group) 
(i) 2011

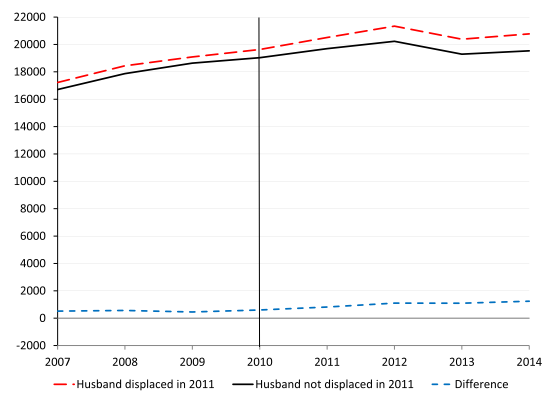

(j) 2012

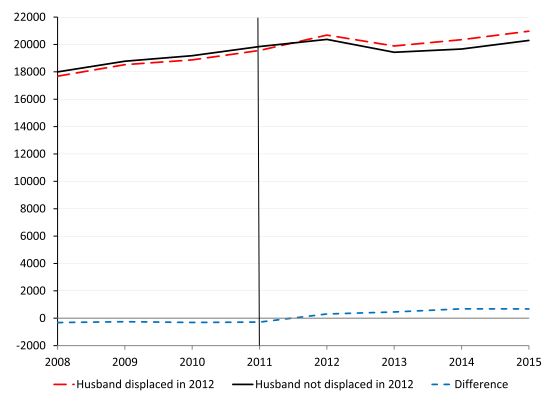

Notes: Own calculations using the Labour Market Panel (Statistics Netherlands). The solid black lines denote the control groups, the red lines denote the treatment groups and the dotted blue lines denote the differences between the treatment group and the control group. Figures for individual treatment years are based on a sample of individuals: with observations available for the full 8-year period, couples that stay together during the full period, 25-55 years of age for both the female and male partner in the year before the treatment year, and with husbands that earn at least 5,000 euro and receive no UI, social assistance or other benefits in the four years before the 'treatment'.

entering UI. This (smaller) increase from year $t$ to year $t+1$ stems from the fact that we use annual data wherein not all male partners become unemployed at the beginning of the year. Three years after entering UI, we still observe a negative treatment effect of about 20 thousand euros.

As expected, our estimation results point at relatively large income losses. This largely stems from the fact that all 'treated' men were affected by job loss in our sample. Using mass layoffs that may or may not result in unemployment, Hardoy \& Schøne (2014) find a 5\% reduction in income which remains approximately the same level in the four years after displacement, while Halla et al. (2020) find a relatively stable decrease in earnings of $21-24 \%$ of the pre-displacement earnings.

To further disentangle the large income drop we find, Supplementary Table A.2 also shows the treatment effect on male partner's probability of being employed. For most treatment years, the employment rate is about 22 percentage points lower in the year after the unemployment shock. Hence, $40-45 \%$ of the negative treatment effect on men's wage income can be explained by being unemployed and more than half is due to lower wages in subsequent employment. ${ }^{10}$

Table 3 shows the AWE estimates, i.e., the treatment effect on the female partner's wage income from work for all year cohorts in our sample. We first

\footnotetext{
${ }^{10}$ This is more than is found in the literature using mass layoffs in the Netherlands. Deelen et al. (2018) estimate a decrease in the employment rate in the year after displacement of 18 percentage points for older age workers (45-54) and 12 percentage points for prime-age workers (35-44) in the Netherlands. Meekes \& Hassink (2019) find a displacement effect on employment of $20 \%$ for the Netherlands. In addition, Deelen et al. (2018) and Meekes \& Hassink (2019) find substantially lower but stable treatment effects on wages, ranging from -3 to $-8 \%$.
} 
Table 2 Treatment effect of entering UI on wage income male partner

\begin{tabular}{|c|c|c|c|c|c|}
\hline & $\begin{array}{l}\text { (1) } \\
\text { (n)03 }\end{array}$ & $\begin{array}{l}\text { (2) } \\
\text { (2)04 }\end{array}$ & $\begin{array}{l}\text { (3) } \\
2005\end{array}$ & $\begin{array}{l}\text { (4) } \\
\text { (2006 }\end{array}$ & $\begin{array}{l}\text { (5) } \\
\text { (2) }\end{array}$ \\
\hline Male partner displaced in $t-2$ & $\begin{array}{l}407 \\
(294)\end{array}$ & $\begin{array}{c}-560 * * \\
(235)\end{array}$ & $\begin{array}{c}-696^{* * * *} \\
(218)\end{array}$ & $\begin{array}{l}-273 \\
(251)\end{array}$ & $\begin{array}{l}-211 \\
(364)\end{array}$ \\
\hline Male partner displaced in $t-1$ & $\begin{array}{l}-106 \\
(304)\end{array}$ & $\begin{array}{l}-273 \\
(328)\end{array}$ & $\begin{array}{l}-382 \\
(315)\end{array}$ & $\begin{array}{c}1364 * * \\
(582)\end{array}$ & $\begin{array}{c}152 \\
(534)\end{array}$ \\
\hline Male partner displaced in $t$ & $\begin{array}{c}-12,223^{* * *} \\
(1413)\end{array}$ & $\begin{array}{c}-13,176^{* * *} \\
(530)\end{array}$ & $\begin{array}{c}-12,621^{* * *} \\
(745)\end{array}$ & $\begin{array}{c}-17,005^{* * *} \\
(736)\end{array}$ & $\begin{array}{c}-13,417 * * * \\
(913)\end{array}$ \\
\hline Male partner displaced in $t+1$ & $\begin{array}{c}-21,793^{* * *} \\
(522)\end{array}$ & $\begin{array}{c}-19,532^{* * *} \\
(504)\end{array}$ & $\begin{array}{c}-21,599^{* * *} \\
(609)\end{array}$ & $\begin{array}{c}-23,434 * * * \\
(739)\end{array}$ & $\begin{array}{c}-21,498 * * * \\
(873)\end{array}$ \\
\hline Male partner displaced in $t+2$ & $\begin{array}{c}-17,697 * * * \\
(517)\end{array}$ & $\begin{array}{c}-15,953^{* * *} \\
(537)\end{array}$ & $\begin{array}{c}-17,882^{* * *} \\
(641)\end{array}$ & $\begin{array}{c}-19,751^{* * *} \\
(773)\end{array}$ & $\begin{array}{c}-19,575^{* * *} \\
(914)\end{array}$ \\
\hline Male partner displaced in $t+3$ & $\begin{array}{c}-16,091^{* * *} \\
(555)\end{array}$ & $\begin{array}{c}-13,733^{* * *} \\
(549)\end{array}$ & $\begin{array}{c}-17,011 * * * \\
(666)\end{array}$ & $\begin{array}{c}-20,279^{* * *} \\
(789)\end{array}$ & $\begin{array}{c}-20,112 * * * \\
(960)\end{array}$ \\
\hline Demographic controls & Yes & Yes & Yes & Yes & Yes \\
\hline Year fixed effects & Yes & Yes & Yes & Yes & Yes \\
\hline Individual fixed effects & Yes & Yes & Yes & Yes & Yes \\
\hline Observations & 999,744 & 982,384 & 966,104 & 940,136 & 912,104 \\
\hline Number of individuals & 124,968 & 122,798 & 120,763 & 117,517 & 114,014 \\
\hline & $\begin{array}{c}(6) \\
2008\end{array}$ & $\begin{array}{c}(7) \\
2009\end{array}$ & $\begin{array}{c}(8) \\
2010\end{array}$ & $\begin{array}{c}(9) \\
2011\end{array}$ & $\begin{array}{c}(10) \\
2012\end{array}$ \\
\hline Male partner displaced in $t-2$ & $\begin{array}{l}-48 \\
(474)\end{array}$ & $\begin{array}{l}-221 \\
(341)\end{array}$ & $\begin{array}{l}-224 \\
(298)\end{array}$ & $\begin{array}{c}124 \\
(689)\end{array}$ & $\begin{array}{c}-599 * * \\
(280)\end{array}$ \\
\hline Male partner displaced in $t-1$ & $\begin{array}{c}1666 \\
(1806)\end{array}$ & $\begin{array}{c}-830^{* * *} \\
(320)\end{array}$ & $\begin{array}{c}-1015^{* * *} \\
(400)\end{array}$ & $\begin{array}{l}-367 \\
(455)\end{array}$ & $\begin{array}{c}-883^{* * *} \\
(344)\end{array}$ \\
\hline Male partner displaced in $t$ & $\begin{array}{c}-14,710^{* * *} \\
(1143)\end{array}$ & $\begin{array}{c}-16,945^{* * * *} \\
(601)\end{array}$ & $\begin{array}{c}-19,471^{* * *} \\
(739)\end{array}$ & $\begin{array}{c}-17,566^{* * *} \\
(689)\end{array}$ & $\begin{array}{c}-18,613 * * * \\
(726)\end{array}$ \\
\hline Male partner displaced in $t+1$ & $\begin{array}{c}-26,172^{* * *} \\
(993)\end{array}$ & $\begin{array}{c}-26,377^{* * *} \\
(658)\end{array}$ & $\begin{array}{c}-27,116^{* * *} \\
(771)\end{array}$ & $\begin{array}{c}-27,204^{* * *} \\
(753)\end{array}$ & $\begin{array}{c}-30,220 * * * \\
(726)\end{array}$ \\
\hline Male partner displaced in $t+2$ & $\begin{array}{c}-22,810^{* * *} \\
(1018)\end{array}$ & $\begin{array}{c}-20,898^{* * *} \\
(648)\end{array}$ & $\begin{array}{c}-24,107^{* * *} \\
(831)\end{array}$ & $\begin{array}{c}-23,696^{* * *} \\
(782)\end{array}$ & $\begin{array}{c}-25,387 * * * \\
(695)\end{array}$ \\
\hline Male partner displaced in $t+3$ & $\begin{array}{c}-21,108^{* * *} \\
(1042)\end{array}$ & $\begin{array}{c}-19,790^{* * *} \\
(620)\end{array}$ & $\begin{array}{c}-22,834 * * * \\
(824)\end{array}$ & $\begin{array}{c}-22,565^{* * *} \\
(815)\end{array}$ & $\begin{array}{c}-23,893 * * * \\
(703)\end{array}$ \\
\hline Demographic controls & Yes & Yes & Yes & Yes & Yes \\
\hline Year fixed effects & Yes & Yes & Yes & Yes & Yes \\
\hline Individual fixed effects & Yes & Yes & Yes & Yes & Yes \\
\hline Observations & 881,768 & 853,176 & 809,928 & 768,176 & 723,512 \\
\hline Number of individuals & 110,222 & 106,648 & 101,242 & 96,023 & 90,441 \\
\hline
\end{tabular}

Standard errors in parentheses. Our sample consists of couples 25-55 years of age in the year before the unemployment shock. Furthermore, we select couples in which the male partner has an annual income from work of at least 5000 euros in the four years before the treatment and does not receive UI, social assistance or other benefits in the pre-treatment period. All specifications include year dummies, time-varying demographic controls (age) and individual fixed effects

$*$ Denotes significance at the $10 \%$ level, $* *$ at the $5 \%$ level and *** at the $1 \%$ level 
Table 3 Treatment effect of entering UI on wage income female partner

\begin{tabular}{|c|c|c|c|c|c|}
\hline & $\begin{array}{l}(1) \\
2003\end{array}$ & $\begin{array}{l}(2) \\
2004\end{array}$ & $\begin{array}{l}(3) \\
2005\end{array}$ & $\begin{array}{l}(4) \\
2006\end{array}$ & $\begin{array}{l}(5) \\
2007\end{array}$ \\
\hline Male partner displaced in $t-2$ & $\begin{array}{l}-1 \\
(120)\end{array}$ & $\begin{array}{l}105 \\
(121)\end{array}$ & $\begin{array}{l}-182 \\
(142)\end{array}$ & $\begin{array}{l}151 \\
(151)\end{array}$ & $\begin{array}{l}220 \\
(188)\end{array}$ \\
\hline Male partner displaced in $t-1$ & $\begin{array}{l}-31 \\
(153)\end{array}$ & $\begin{array}{l}96 \\
(146)\end{array}$ & $\begin{array}{l}-176 \\
(173)\end{array}$ & $\begin{array}{l}112 \\
(195)\end{array}$ & $\begin{array}{l}528^{*} \\
(298)\end{array}$ \\
\hline Male partner displaced in $t$ & $\begin{array}{l}495^{* * *} \\
(192)\end{array}$ & $\begin{array}{l}607 * * * \\
(178)\end{array}$ & $\begin{array}{l}24 \\
(189)\end{array}$ & $\begin{array}{l}557 * * \\
(229)\end{array}$ & $\begin{array}{l}669 * * \\
(291)\end{array}$ \\
\hline Male partner displaced in $t+1$ & $\begin{array}{l}926 * * * \\
(211)\end{array}$ & $\begin{array}{l}998 * * * \\
(207)\end{array}$ & $\begin{array}{l}225 \\
(211)\end{array}$ & $\begin{array}{l}849 * * * \\
(268)\end{array}$ & $\begin{array}{l}1,102 * * * \\
(350)\end{array}$ \\
\hline Male partner displaced in $t+2$ & $\begin{array}{l}855^{* * *} \\
(213)\end{array}$ & $\begin{array}{l}858 * * * \\
(217)\end{array}$ & $\begin{array}{l}396 \\
(242)\end{array}$ & $\begin{array}{l}729 * * \\
(307)\end{array}$ & $\begin{array}{l}897 * * \\
(360)\end{array}$ \\
\hline Male partner displaced in $t+3$ & $\begin{array}{l}968 * * * \\
(242)\end{array}$ & $\begin{array}{l}970 * * * \\
(252)\end{array}$ & $\begin{array}{l}107 \\
(284)\end{array}$ & $\begin{array}{l}297 \\
(342)\end{array}$ & $\begin{array}{l}1,482 * * * \\
(395)\end{array}$ \\
\hline Demographic controls & Yes & Yes & Yes & Yes & Yes \\
\hline Year fixed effects & Yes & Yes & Yes & Yes & Yes \\
\hline Individual fixed effects & Yes & Yes & Yes & Yes & Yes \\
\hline Observations & 999,744 & 982,384 & 966,104 & 940,136 & 912,104 \\
\hline Number of individuals & 124,968 & 122,798 & 120,763 & 117,517 & 114,014 \\
\hline & $\begin{array}{l}(6) \\
2008\end{array}$ & $\begin{array}{l}(7) \\
2009\end{array}$ & $\begin{array}{l}8) \\
2010\end{array}$ & $\begin{array}{l}\text { (9) } \\
2011\end{array}$ & $\begin{array}{l}\text { (10) } \\
2012\end{array}$ \\
\hline Male partner displaced in $t-2$ & $\begin{array}{l}-214 \\
(194)\end{array}$ & $\begin{array}{l}-178 \\
(132)\end{array}$ & $\begin{array}{l}53 \\
(135)\end{array}$ & $\begin{array}{l}-86 \\
(163)\end{array}$ & $\begin{array}{l}-26 \\
(120)\end{array}$ \\
\hline Male partner displaced in $t-1$ & $\begin{array}{l}-392 * \\
(231)\end{array}$ & $\begin{array}{l}-308^{*} \\
(173)\end{array}$ & $\begin{array}{l}38 \\
(165)\end{array}$ & $\begin{array}{l}68 \\
(187)\end{array}$ & $\begin{array}{l}2 \\
(169)\end{array}$ \\
\hline Male partner displaced in $t$ & $\begin{array}{l}-124 \\
(303)\end{array}$ & $\begin{array}{l}-99 \\
(207)\end{array}$ & $\begin{array}{l}285 \\
(195)\end{array}$ & $\begin{array}{l}293 \\
(235)\end{array}$ & $\begin{array}{l}604 * * * \\
(200)\end{array}$ \\
\hline Male partner displaced in $t+1$ & $\begin{array}{l}195 \\
(418)\end{array}$ & $\begin{array}{l}344 * \\
(232)\end{array}$ & $\begin{array}{l}470 * * \\
(221)\end{array}$ & $\begin{array}{l}585^{* * *} \\
(258)\end{array}$ & $\begin{array}{l}761 * * * \\
(225)\end{array}$ \\
\hline Male partner displaced in $t+2$ & $\begin{array}{l}-77 \\
(450)\end{array}$ & $\begin{array}{l}294 \\
(267)\end{array}$ & $\begin{array}{l}501 * * \\
(248)\end{array}$ & $\begin{array}{l}574 * * \\
(264)\end{array}$ & $\begin{array}{l}992 * * \\
(256)\end{array}$ \\
\hline Male partner displaced in $t+3$ & $\begin{array}{l}-80 \\
(471)\end{array}$ & $\begin{array}{l}156 \\
(273)\end{array}$ & $\begin{array}{l}461 * \\
(251)\end{array}$ & $\begin{array}{l}718^{* *} \\
(291)\end{array}$ & $\begin{array}{l}1,001 * * * \\
(280)\end{array}$ \\
\hline Demographic controls & Yes & Yes & Yes & Yes & Yes \\
\hline Year fixed effects & Yes & Yes & Yes & Yes & Yes \\
\hline Individual fixed effects & Yes & Yes & Yes & Yes & Yes \\
\hline Observations & 881,768 & 853,176 & 809,928 & 768,176 & 723,512 \\
\hline Number of individuals & 110,222 & 106,648 & 101,242 & 96,023 & 90,441 \\
\hline
\end{tabular}

Standard errors in parentheses. Our sample consists of couples 25-55 years of age in the year before the unemployment shock. Furthermore, we select couples in which the male partner has an annual income from work of at least 5000 euros in the four years before the treatment and does not receive UI, social assistance or other benefits in the pre-treatment period. All specifications include year dummies, time-varying demographic controls (age) and individual fixed effects

*Denotes significance at the $10 \%$ level, ** at the $5 \%$ level and *** at the $1 \%$ level 
consider the placebo treatment dummies for $t-2$ and $t-1$, which are typically small and statistically insignificant. ${ }^{11}$ The treatment effect varies across years, but is typically in the order of 500-1000 euros in the years after the male partner enters UI. The AWE is rather stable over the years following entry into UI, corresponding to $2-5 \%$ of the income shock for the male partner. Hardoy \& Schøne (2014) find an AWE of 7-18\% of a much smaller income shock and Halla et al. (2020) find an AWE of 0.6-1.5\%. For 2008 and 2009, the start of the Great Recession, the AWE estimates are statistically insignificant. ${ }^{12}$ In line with the findings of Halla et al. (2020), depressed labour demand may have muted the AWE on realized income increases, as female partners could not find a job or extend their working hours. Finding a smaller AWE during an economic downturn is also in line with Maloney $(1987,1991)$, Juhn \& Potter (2007) and Bryan \& Longhi (2018). Later on, from 2010 onwards, the AWE resurfaces.

We next broaden our analysis to the total income from wages and profits (from self-employment) of female partners, defining the 'total AWE' as the effect on the sum of wage and profit income. With a larger share of self-employment, one might expect that the AWE from this source may have become more important as well. Figure $3^{13}$ and Table 4 present this combined treatment effect on female partner's wage income and profit income from self-employment, while Supplementary Table A.3 shows the effects for profit income only. We find a total AWE for the different treatment years of 800-2100 euros, which is $3-10 \%$ of male partner's income loss. Turning to the isolated the AWEs from profits shown in Supplementary Table A.3, we generally see a rise in the importance of income from self-employment. According to these estimates, the AWE via profit income of the female partner rises to about 500 euros three years after the male entered UI. This effect corresponds to about $2 \%$ of the initial income loss of the male partner. This implies that a substantial share of the total AWE runs through increased profits from self-employment, next to the effect from increased wage earnings of the female partner.

\subsection{Robustness and heterogeneous effects}

Alongside the use of placebo dummies to test for parallel trends in our benchmark models, we have considered various alternative regressions with different sets of controls, different clustering levels and different definitions of 'shocks' and samples that define the treated group of male partners. The corresponding results are all shown in tables in the supplementary material to this paper. For expositional reasons, most of these tables present our results on the 'total' AWE (that includes profits) for the years 2004, 2008 and 2012.

Supplementary Table A.4 shows the results with an increasing number of control variables. The first column presents the results with year fixed effects and a group dummy, demographic controls are added in the second model and the third

\footnotetext{
${ }^{11}$ With the exception for the dummy for $t-1$ for female partners of male partners that become unemployed in 2007-2009, where the placebo dummy is significant at the $10 \%$ level.

${ }^{12}$ However, Table 4 shows that we still find an AWE for 2008 and 2009 on female partner's profits.

${ }^{13}$ For expositional reasons, we only show the AWE in Fig. 3 for 2004, 2008 and 2012 as reference years.
} 


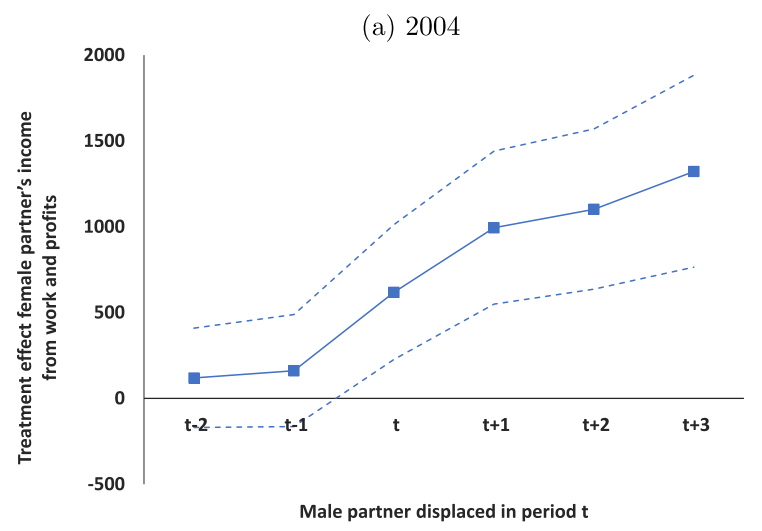

(b) 2008

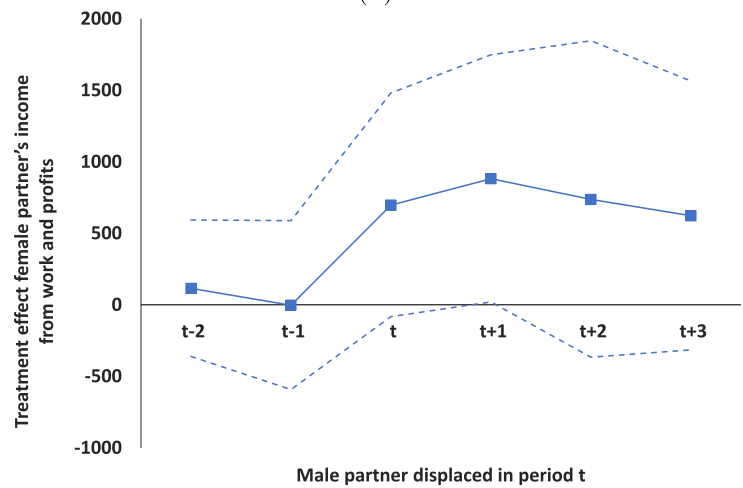

(c) 2012

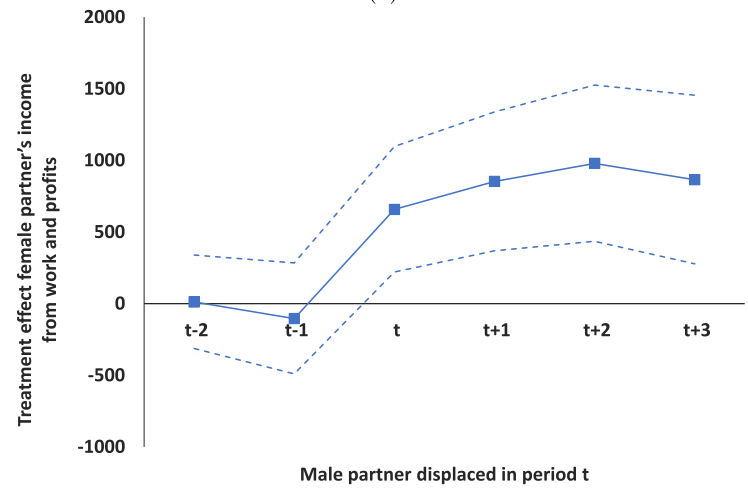

Fig. 3 Treatment effect of entering UI on female partner's income from work and profits ('total AWE) in 2004, 2008 and 2012. This figure is derived from the regression results also presented in Table 4. The blue squares give the regression coefficients and the blue dotted lines denote the $95 \%$ confidence intervals

model gives our preferred model where we add individual fixed effects. Our key results are robust across these models. Supplementary Table A.5 shows that the 
Table 4 Treatment effect of entering into UI on female partner's income from work and profits ('total' AWE)

\begin{tabular}{|c|c|c|c|c|c|}
\hline & $\begin{array}{l}(1) \\
2003\end{array}$ & $\begin{array}{l}(2) \\
2004\end{array}$ & $\begin{array}{l}(3) \\
2005\end{array}$ & $\begin{array}{l}(4) \\
2006\end{array}$ & $\begin{array}{l}(5) \\
2007\end{array}$ \\
\hline Male partner displaced in $t-2$ & $\begin{array}{l}-99 \\
(133)\end{array}$ & $\begin{array}{l}119 \\
(148)\end{array}$ & $\begin{array}{l}-138 \\
(154)\end{array}$ & $\begin{array}{l}352^{*} \\
(201)\end{array}$ & $\begin{array}{l}216 \\
(222)\end{array}$ \\
\hline Male partner displaced in $t-1$ & $\begin{array}{l}-131 \\
(166)\end{array}$ & $\begin{array}{l}161 \\
(167)\end{array}$ & $\begin{array}{l}-137 \\
(188)\end{array}$ & $\begin{array}{l}242 \\
(226)\end{array}$ & $\begin{array}{l}626^{*} \\
(342)\end{array}$ \\
\hline Male partner displaced in $t$ & $\begin{array}{l}624 * * * \\
(208)\end{array}$ & $\begin{array}{l}618^{* * *} \\
(201)\end{array}$ & $\begin{array}{l}217 \\
(235)\end{array}$ & $\begin{array}{l}1095^{* * *} \\
(409)\end{array}$ & $\begin{array}{l}842 * * \\
(350)\end{array}$ \\
\hline Male partner displaced in $t+1$ & $\begin{array}{l}1152^{* * *} \\
(232)\end{array}$ & $\begin{array}{l}994 * * * \\
(228)\end{array}$ & $\begin{array}{l}506 * * \\
(244)\end{array}$ & $\begin{array}{l}1026 * * * \\
(294)\end{array}$ & $\begin{array}{l}1703^{* * *} \\
(443)\end{array}$ \\
\hline Male partner displaced in $t+2$ & $\begin{array}{l}1122^{* * *} \\
(251)\end{array}$ & $\begin{array}{l}1102^{* * *} \\
(239)\end{array}$ & $\begin{array}{l}749 * * \\
(292)\end{array}$ & $\begin{array}{l}1076^{* * *} \\
(343)\end{array}$ & $\begin{array}{l}1393^{* * *} \\
(424)\end{array}$ \\
\hline Male partner displaced in $t+3$ & $\begin{array}{l}1313 * * * \\
(271)\end{array}$ & $\begin{array}{l}1322^{* * * *} \\
(286)\end{array}$ & $\begin{array}{l}798^{* *} \\
(366)\end{array}$ & $\begin{array}{l}850 * * \\
(394)\end{array}$ & $\begin{array}{l}2151^{* * *} \\
(469)\end{array}$ \\
\hline Demographic controls & Yes & Yes & Yes & Yes & Yes \\
\hline Year fixed effects & Yes & Yes & Yes & Yes & Yes \\
\hline Individual fixed effects & Yes & Yes & Yes & Yes & Yes \\
\hline Observations & 999,744 & 982,384 & 966,104 & 940,136 & 912,104 \\
\hline \multirow[t]{2}{*}{ Number of individuals } & 124,968 & 122,798 & 120,763 & 117,517 & 114,014 \\
\hline & $\begin{array}{l}(6) \\
2008\end{array}$ & $\begin{array}{l}(7) \\
2009\end{array}$ & $\begin{array}{l}(8) \\
2010\end{array}$ & $\begin{array}{l}(9) \\
2011\end{array}$ & $\begin{array}{l}(10) \\
2012\end{array}$ \\
\hline Male partner displaced in $t-2$ & $\begin{array}{l}115 \\
(244)\end{array}$ & $\begin{array}{l}-178 \\
(138)\end{array}$ & $\begin{array}{l}38 \\
(165)\end{array}$ & $\begin{array}{l}-26 \\
(170)\end{array}$ & $\begin{array}{l}12 \\
(167)\end{array}$ \\
\hline Male partner displaced in $t-1$ & $\begin{array}{l}-3 \\
(302)\end{array}$ & $\begin{array}{l}-147 \\
(176)\end{array}$ & $\begin{array}{l}51 \\
(188)\end{array}$ & $\begin{array}{l}214 \\
(201)\end{array}$ & $\begin{array}{l}-104 \\
(198)\end{array}$ \\
\hline Male partner displaced in $t$ & $\begin{array}{l}697 * \\
(400)\end{array}$ & $\begin{array}{l}174 \\
(223)\end{array}$ & $\begin{array}{l}283 \\
(212)\end{array}$ & $\begin{array}{l}673 * * * \\
(249)\end{array}$ & $\begin{array}{l}658^{* * * *} \\
(224)\end{array}$ \\
\hline Male partner displaced in $t+1$ & $\begin{array}{l}882 * * \\
(442)\end{array}$ & $\begin{array}{l}727 * * * \\
(249)\end{array}$ & $\begin{array}{l}593 * * * \\
(229)\end{array}$ & $\begin{array}{l}1064 * * * \\
(267)\end{array}$ & $\begin{array}{l}853^{* * *} \\
(248)\end{array}$ \\
\hline Male partner displaced in $t+2$ & $\begin{array}{l}737 \\
(566)\end{array}$ & $\begin{array}{l}661 * * \\
(276)\end{array}$ & $\begin{array}{l}839 * * * \\
(265)\end{array}$ & $\begin{array}{l}1100 * * * \\
(293)\end{array}$ & $\begin{array}{l}979 * * * \\
(279)\end{array}$ \\
\hline Male partner displaced in $t+3$ & $\begin{array}{l}623 \\
(481)\end{array}$ & $\begin{array}{l}565^{*} \\
(298)\end{array}$ & $\begin{array}{l}611 * * \\
(259)\end{array}$ & $\begin{array}{l}1272 * * * \\
(304)\end{array}$ & $\begin{array}{l}865^{* * *} \\
(301)\end{array}$ \\
\hline Demographic controls & Yes & Yes & Yes & Yes & Yes \\
\hline Year fixed effects & Yes & Yes & Yes & Yes & Yes \\
\hline Individual fixed effects & Yes & Yes & Yes & Yes & Yes \\
\hline Observations & 881,768 & 853,176 & 809,928 & 768,176 & 723,512 \\
\hline Number of individuals & 110,222 & 106,648 & 101,242 & 96,023 & 90,441 \\
\hline
\end{tabular}

Standard errors in parentheses. Our sample consists of couples 25-55 years of age in the year before the unemployment shock. Furthermore, we select couples in which the male partner has an annual income from work of at least 5000 euros in the four years before the treatment and does not receive UI, social assistance or other benefits in the pre-treatment period. All specifications include year dummies, time-varying demographic controls (age) and individual fixed effects

*Denotes significance at the $10 \%$ level, $* *$ at the $5 \%$ level and *** at the $1 \%$ level 
levels of significance do not change when we use different levels of clustering of the standard errors. ${ }^{14}$

As an alternative to partners that enter into UI, we have also estimated the total AWE induced by a large negative shock (not necessarily related to entering UI) on male partner's total income (wages plus profits). Supplementary Tables A.6 and A.7 consider the AWE of a negative income shock of at least 20 and $50 \%$, respectively, in total income of the male worker. Many of the pre-treatment placebo AWE dummies are statistically significant for this treatment group, which violates the assumption of common time effects. This casts doubts on the exogeneity of income shocks, and hence we prefer our treatment of entering UI. As another robustness check, we used different threshold values for the male partners earned income that define the treatment and control groups. Supplementary Table A.8 shows that threshold values of (less than) 0,5000 or 15,000 euros in the years before the male partner became unemployed yields similar AWE estimates. ${ }^{15} \mathrm{We}$ also find a similar AWE when we shorten our samples to six years in which we observe couples that are together and observed in the data for six years (see Supplementary Table A.10). ${ }^{16}$ Using 6-year samples also allows us to study the effect for the years 2013 and 2014, for which we find an AWE of 700 and 510 euros one year after the male entered UI.

Finally, we have studied heterogeneity in the AWE across age, gender and income groups for the treatment years 2004, 2008 and 2012. Supplementary Table A.14 gives the AWE for different age groups. For the treatment years 2004 and 2012, we find a larger AWE for young (25-35) and middle-aged (36-45) women, and no AWE for women 46-55 years of age. Supplementary Table A.15 shows that the AWE for couples with children is about half the size of the AWE for couples without children. A plausible explanation is that the costs of changing roles within these households are larger than without children. Supplementary Table A.16 presents the AWE for women with a low, middle or high level of education. For highly educated women, we find a higher AWE and for loweducated women, we find no AWE at all. This may point to worse labour prospects for this group. Supplementary Table A.17 gives the AWE for female partners with different ethnic backgrounds. The largest effects are obtained for natives and western immigrants, and no effect for non-western immigrants. Lastly, Supplementary Table A.18 shows the AWE for women with male partners within different income groups (measured before the unemployment shock). The AWE increases with the income of the male partner (before unemployment shock), suggesting that larger initial income shocks from the partner are compensated with a larger AWE.

\footnotetext{
14 The exception is the placebo for $t-1$ for 2008 that changes from statistically significant at the $10 \%$ level in our preferred specification with 'clustering' at the individual level to insignificant with the other levels of clustering.

15 In Supplementary Table A.9, we exclude couples working in the same sector, so that the AWE is not 'contaminated' by common sectoral shocks (Hardoy \& Schøne, 2014). This yields AWE estimates that are somewhat larger (one tenth to one fifth larger).

16 Using a 6-year rather than an 8-year period addresses the concern that our samples may not be representative for the full population. About $40 \%$ of our couples are excluded from our samples because they do not stay together for 8 years or are not observed during the full 8 -year period.
} 
Table 5 Treatment effect of entering UI on female partner's income from work: extensive margin effects

\begin{tabular}{|c|c|c|c|c|c|}
\hline & $\begin{array}{l}(1) \\
2003\end{array}$ & $\begin{array}{l}(2) \\
2004\end{array}$ & $\begin{array}{l}(3) \\
2005\end{array}$ & $\begin{array}{l}(4) \\
2006\end{array}$ & $\begin{array}{l}(5) \\
2007\end{array}$ \\
\hline Male partner displaced in $t-2$ & $\begin{array}{l}165 \\
(184)\end{array}$ & $\begin{array}{l}23 \\
(162)\end{array}$ & $\begin{array}{l}17 \\
(157)\end{array}$ & $\begin{array}{l}-118 \\
(140)\end{array}$ & $\begin{array}{l}534 * \\
(308)\end{array}$ \\
\hline Male partner displaced in $t-1$ & $\begin{array}{l}317 \\
(216)\end{array}$ & $\begin{array}{l}119 \\
(207)\end{array}$ & $\begin{array}{l}294 \\
(219)\end{array}$ & $\begin{array}{l}56 \\
(201)\end{array}$ & $\begin{array}{l}208 \\
(481)\end{array}$ \\
\hline Male partner displaced in $t$ & $\begin{array}{l}644 * * \\
(167)\end{array}$ & $\begin{array}{l}763 * * \\
(186)\end{array}$ & $\begin{array}{l}371 \\
(230)\end{array}$ & $\begin{array}{l}665^{* *} \\
(264)\end{array}$ & $\begin{array}{l}762 \\
(340)\end{array}$ \\
\hline Male partner displaced in $t+1$ & $\begin{array}{l}768 * * * \\
(279)\end{array}$ & $\begin{array}{l}1188^{* * * *} \\
(368)\end{array}$ & $\begin{array}{l}813^{* * *} \\
(350)\end{array}$ & $\begin{array}{l}1,093 * * * \\
(421)\end{array}$ & $\begin{array}{l}980 \\
(613)\end{array}$ \\
\hline Male partner displaced in $t+2$ & $\begin{array}{l}1024 * * * \\
(302)\end{array}$ & $\begin{array}{l}1141^{* * * *} \\
(396)\end{array}$ & $\begin{array}{l}1090^{* *} \\
(471)\end{array}$ & $\begin{array}{l}971^{* *} \\
(433)\end{array}$ & $\begin{array}{l}789 \\
(618)\end{array}$ \\
\hline Male partner displaced in $t+3$ & $\begin{array}{l}1238 * * * \\
(364)\end{array}$ & $\begin{array}{l}1280^{* * * *} \\
(454)\end{array}$ & $\begin{array}{l}1195^{* *} \\
(508)\end{array}$ & $\begin{array}{l}586 \\
(449)\end{array}$ & $\begin{array}{l}1135^{*} \\
(667)\end{array}$ \\
\hline Demographic controls & Yes & Yes & Yes & Yes & Yes \\
\hline Year fixed effects & Yes & Yes & Yes & Yes & Yes \\
\hline Individual fixed effects & Yes & Yes & Yes & Yes & Yes \\
\hline Observations & 285,808 & 257,376 & 220,560 & 204,632 & 191,560 \\
\hline Number of individuals & 35,726 & 32,172 & 27,570 & 25,579 & 23,945 \\
\hline & $\begin{array}{l}\text { (6) } \\
2008\end{array}$ & $\begin{array}{l}\text { (7) } \\
2009\end{array}$ & $\begin{array}{l}(8) \\
2010\end{array}$ & $\begin{array}{l}(9) \\
2011\end{array}$ & $\begin{array}{l}(10) \\
2012\end{array}$ \\
\hline Male partner displaced in $t-2$ & $\begin{array}{l}-49 \\
(235)\end{array}$ & $\begin{array}{l}62 \\
(185)\end{array}$ & $\begin{array}{l}247 \\
(228)\end{array}$ & $\begin{array}{l}308 \\
(475)\end{array}$ & $\begin{array}{l}-393 * * * \\
(126)\end{array}$ \\
\hline Male partner displaced in $t-1$ & $\begin{array}{l}-17 \\
(337)\end{array}$ & $\begin{array}{l}13 \\
(258)\end{array}$ & $\begin{array}{l}565^{*} \\
(307)\end{array}$ & $\begin{array}{l}-162 \\
(302)\end{array}$ & $\begin{array}{l}-488^{* *} \\
(211)\end{array}$ \\
\hline Male partner displaced in $t$ & $\begin{array}{l}57 \\
(467)\end{array}$ & $\begin{array}{l}414 \\
(313)\end{array}$ & $\begin{array}{l}772 * * \\
(351)\end{array}$ & $\begin{array}{l}25 \\
(401)\end{array}$ & $\begin{array}{l}-516^{* *} \\
(261)\end{array}$ \\
\hline Male partner displaced in $t+1$ & $\begin{array}{l}1619 \\
(1199)\end{array}$ & $\begin{array}{l}692 * \\
(358)\end{array}$ & $\begin{array}{l}914 * * \\
(400)\end{array}$ & $\begin{array}{l}121 \\
(428)\end{array}$ & $\begin{array}{l}-587 * * \\
(281)\end{array}$ \\
\hline Male partner displaced in $t+2$ & $\begin{array}{l}1127 \\
(1215)\end{array}$ & $\begin{array}{l}582 \\
(388)\end{array}$ & $\begin{array}{l}930 * * \\
(421)\end{array}$ & $\begin{array}{l}273 \\
(479)\end{array}$ & $\begin{array}{l}-508 \\
(320)\end{array}$ \\
\hline Male partner displaced in $t+3$ & $\begin{array}{l}1300 \\
(1254)\end{array}$ & $\begin{array}{l}971^{* *} \\
(437)\end{array}$ & $\begin{array}{l}785^{*} \\
(426)\end{array}$ & $\begin{array}{l}552 \\
(537)\end{array}$ & $\begin{array}{l}-614^{*} \\
(343)\end{array}$ \\
\hline Demographic controls & Yes & Yes & Yes & Yes & Yes \\
\hline Year fixed effects & Yes & Yes & Yes & Yes & Yes \\
\hline Individual fixed effects & Yes & Yes & Yes & Yes & Yes \\
\hline Observations & 183,920 & 174,216 & 156,944 & 137,168 & 122,752 \\
\hline Number of individuals & 22,990 & 21,777 & 19,618 & 17,146 & 15,344 \\
\hline
\end{tabular}

Standard errors in parentheses. Our sample consists of couples 25-55 years of age in the year before the unemployment shock. Furthermore, we select couples in which the husband has an annual income from work of at least 5000 euros in the four years before the treatment and with the husband not receiving income from UI, social assistance or other benefits in the pre-treatment period. All specifications include year dummies, time-varying demographic controls (age) and individual fixed effects.

*Denotes significance at the $10 \%$ level, $* *$ at the $5 \%$ level and *** at the $1 \%$ level 
Table 6 Treatment effect of entering UI on female partner's income from work: intensive margin effects

\begin{tabular}{|c|c|c|c|c|c|}
\hline & $\begin{array}{l}(1) \\
2003\end{array}$ & $\begin{array}{l}(2) \\
2004\end{array}$ & $\begin{array}{l}(3) \\
2005\end{array}$ & $\begin{array}{l}(4) \\
2006\end{array}$ & $\begin{array}{l}(5) \\
2007\end{array}$ \\
\hline Male partner displaced in $t-2$ & $\begin{array}{l}-71 \\
(152)\end{array}$ & $\begin{array}{l}133 \\
(152)\end{array}$ & $\begin{array}{l}-240 \\
(177)\end{array}$ & $\begin{array}{l}209 \\
(198)\end{array}$ & $\begin{array}{l}103 \\
(227)\end{array}$ \\
\hline Male partner displaced in $t-1$ & $\begin{array}{l}-184 \\
(196)\end{array}$ & $\begin{array}{l}93 \\
(183)\end{array}$ & $\begin{array}{l}-308 \\
(213)\end{array}$ & $\begin{array}{l}77 \\
(252)\end{array}$ & $\begin{array}{l}632 * \\
(361)\end{array}$ \\
\hline Male partner displaced in $t$ & $\begin{array}{l}417^{*} \\
(250)\end{array}$ & $\begin{array}{l}558^{* * *} \\
(213)\end{array}$ & $\begin{array}{l}-79 \\
(232)\end{array}$ & $\begin{array}{l}469 \\
(288)\end{array}$ & $\begin{array}{l}652 * \\
(340)\end{array}$ \\
\hline Male partner displaced in $t+1$ & $\begin{array}{l}971^{* * * *} \\
(275)\end{array}$ & $\begin{array}{l}936^{* * *} \\
(247)\end{array}$ & $\begin{array}{l}45 \\
(250)\end{array}$ & $\begin{array}{l}715^{* * *} \\
(329)\end{array}$ & $\begin{array}{l}1,171^{* * *} \\
(418)\end{array}$ \\
\hline Male partner displaced in $t+2$ & $\begin{array}{l}762 * * * \\
(273)\end{array}$ & $\begin{array}{l}762 * * * \\
(258)\end{array}$ & $\begin{array}{l}181 \\
(279)\end{array}$ & $\begin{array}{l}614 \\
(385)\end{array}$ & $\begin{array}{l}969 * * \\
(432)\end{array}$ \\
\hline Male partner displaced in $t+3$ & $\begin{array}{l}838^{* * * *} \\
(306)\end{array}$ & $\begin{array}{l}863 * * * \\
(301)\end{array}$ & $\begin{array}{l}-229 \\
(334)\end{array}$ & $\begin{array}{l}172 \\
(433)\end{array}$ & $\begin{array}{l}1,637 * * * \\
(476)\end{array}$ \\
\hline Demographic controls & Yes & Yes & Yes & Yes & Yes \\
\hline Year fixed effects & Yes & Yes & Yes & Yes & Yes \\
\hline Individual fixed effects & Yes & Yes & Yes & Yes & Yes \\
\hline Observations & 713,936 & 725,008 & 745,544 & 735,504 & 720,544 \\
\hline Number of individuals & 89,242 & 90,626 & 93,193 & 91,938 & 90,069 \\
\hline & $\begin{array}{l}\text { (6) } \\
2008\end{array}$ & $\begin{array}{l}\text { (7) } \\
2009\end{array}$ & $\begin{array}{l}(8) \\
2010\end{array}$ & $\begin{array}{l}(9) \\
2011\end{array}$ & $\begin{array}{l}(10) \\
2012\end{array}$ \\
\hline Male partner displaced in $t-2$ & $\begin{array}{l}-262 \\
(241)\end{array}$ & $\begin{array}{l}-247 \\
(159)\end{array}$ & $\begin{array}{l}2 \\
(159)\end{array}$ & $\begin{array}{l}-164 \\
(172)\end{array}$ & $\begin{array}{l}49 \\
(145)\end{array}$ \\
\hline Male partner displaced in $t-1$ & $\begin{array}{l}-506^{*} \\
(283)\end{array}$ & $\begin{array}{l}-400 * \\
(207)\end{array}$ & $\begin{array}{l}-94 \\
(191)\end{array}$ & $\begin{array}{l}121 \\
(216)\end{array}$ & $\begin{array}{l}101 \\
(202)\end{array}$ \\
\hline Male partner displaced in $t$ & $\begin{array}{l}-171 \\
(368)\end{array}$ & $\begin{array}{l}-245 \\
(247)\end{array}$ & $\begin{array}{l}161 \\
(226)\end{array}$ & $\begin{array}{l}349 \\
(270)\end{array}$ & $\begin{array}{l}850^{* * * *} \\
(239)\end{array}$ \\
\hline Male partner displaced in $t+1$ & $\begin{array}{l}-213 \\
(408)\end{array}$ & $\begin{array}{l}239 \\
(278)\end{array}$ & $\begin{array}{l}353 \\
(257)\end{array}$ & $\begin{array}{l}679 * * \\
(298)\end{array}$ & $\begin{array}{l}1,028 * * * \\
(269)\end{array}$ \\
\hline Male partner displaced in $t+2$ & $\begin{array}{l}-416 \\
(459)\end{array}$ & $\begin{array}{l}203 \\
(322)\end{array}$ & $\begin{array}{l}384 \\
(291)\end{array}$ & $\begin{array}{l}651^{* *} \\
(302)\end{array}$ & $\begin{array}{l}1,295^{* * *} \\
(306)\end{array}$ \\
\hline Male partner displaced in $t+3$ & $\begin{array}{l}-469 \\
(486)\end{array}$ & $\begin{array}{l}-74 \\
(326)\end{array}$ & $\begin{array}{l}368 \\
(293)\end{array}$ & $\begin{array}{l}765 * * \\
(332)\end{array}$ & $\begin{array}{l}1335^{* * * *} \\
(335)\end{array}$ \\
\hline Demographic controls & Yes & Yes & Yes & Yes & Yes \\
\hline Year fixed effects & Yes & Yes & Yes & Yes & Yes \\
\hline Individual fixed effects & Yes & Yes & Yes & Yes & Yes \\
\hline Observations & 697,848 & 678,960 & 652,984 & 631,008 & 600,752 \\
\hline Number of individuals & 87,232 & 84,871 & 81,624 & 78,877 & 75,095 \\
\hline
\end{tabular}

Standard errors in parentheses. Our sample consists of couples 25-55 years of age in the year before the unemployment shock. Furthermore, we select couples in which the husband has an annual income from work of at least 5000 euros in the four years before the treatment and with the husband not receiving income from UI, social assistance or other benefits in the pre-treatment period. All specifications include year dummies, time-varying demographic controls (age) and individual fixed effects

*Denotes significance at the $10 \%$ level, $* *$ at the $5 \%$ level and *** at the $1 \%$ level 


\subsection{Intensive or extensive margin effects?}

We argued earlier that the Netherlands stands out as a country with a high share of part-time female employment, and has witnessed a steep rise in the female employment rate. This may have affected the room for the AWE both at the extensive and the intensive margin over time. Tables 5 and 6 give the treatment effect on female partner's income from work at the extensive and the intensive margin, respectively. In our context, the extensive margin effect gives the effect on female partner's wage income for a sample of households in which the female partner was not employed in year $t-4$; the intensive margin effect gives the effect on female partner's wage income for the remaining sample of households in which the female partner was employed in year $t-4$. Following this approach, we find that extensive margin effects exceed intensive margin effects for the treatment years 2003-2009. For the treatment years 2010-2012, however, extensive margin effects are virtually absent. ${ }^{17}$ This may be related to the strong increase in the female employment rate in the time period under consideration. This trend may have reduced the room for extensive margin effects over time.

Zooming into the first years of the Great Recession (2008-2010) in Table 6, it is interesting to see that intensive margin effects are small while extensive margin effects remained unaffected. As an explanation, Bredtmann et al. (2018) argue that the decrease in intensive margin effects may result from labour hoarding. That is, firms might first cut down the working hours of those already employed, before having to rely on layoffs to reduce their overall costs. These hoarding effects may render it difficult to increase hours worked in the firm in which someone is employed.

As an alternative to female partner's income from wages and profits, we also analyzed the intensive and extensive margin effects on employment. The results are shown in Supplementary Table A.12. Employment is defined by either receiving wage earnings and/or income from profits. For most treatment years, these 'added' employment effects are about 1-2 percentage points for the full sample, which is $1-3 \%$ relative to the employment rate in the years before entering UI. ${ }^{18}$ Supplementary Table A.13 shows that the treatment effect on female partner's annual hours worked for the treatment years $2010-2012$ is $21-43 \mathrm{~h}$ after three years. ${ }^{19}$ This is $2-5 \%$ relative to the number of hours worked in the years before the male enters UI.

\subsection{How much of the income shock is covered?}

Following Hardoy \& Schøne (2014), we finally consider how much of the income shock from unemployment is covered by various types of benefits and other sources

\footnotetext{
17 We have to interpret the results of Table 5 for the treatment year 2012 with the appropriate care, as we find counter-intuitive negative treatment effects as well as a negative statistically significant pre-treatment placebo dummy. We do not find negative effects when we consider the extensive margin effect on participation (rather than on income)—see Supplementary Table A.11.
}

18 Supplementary Table A.11 shows that the effects on participation for the extensive margin sample, consisting of women who did not yet work in $t-4$, is $3-7$ percentage points.

19 Data on hours worked is only available for the shorter period 2006-2015. 
Table 7 Effect of male partner becoming unemployed in 2004 on different income sources

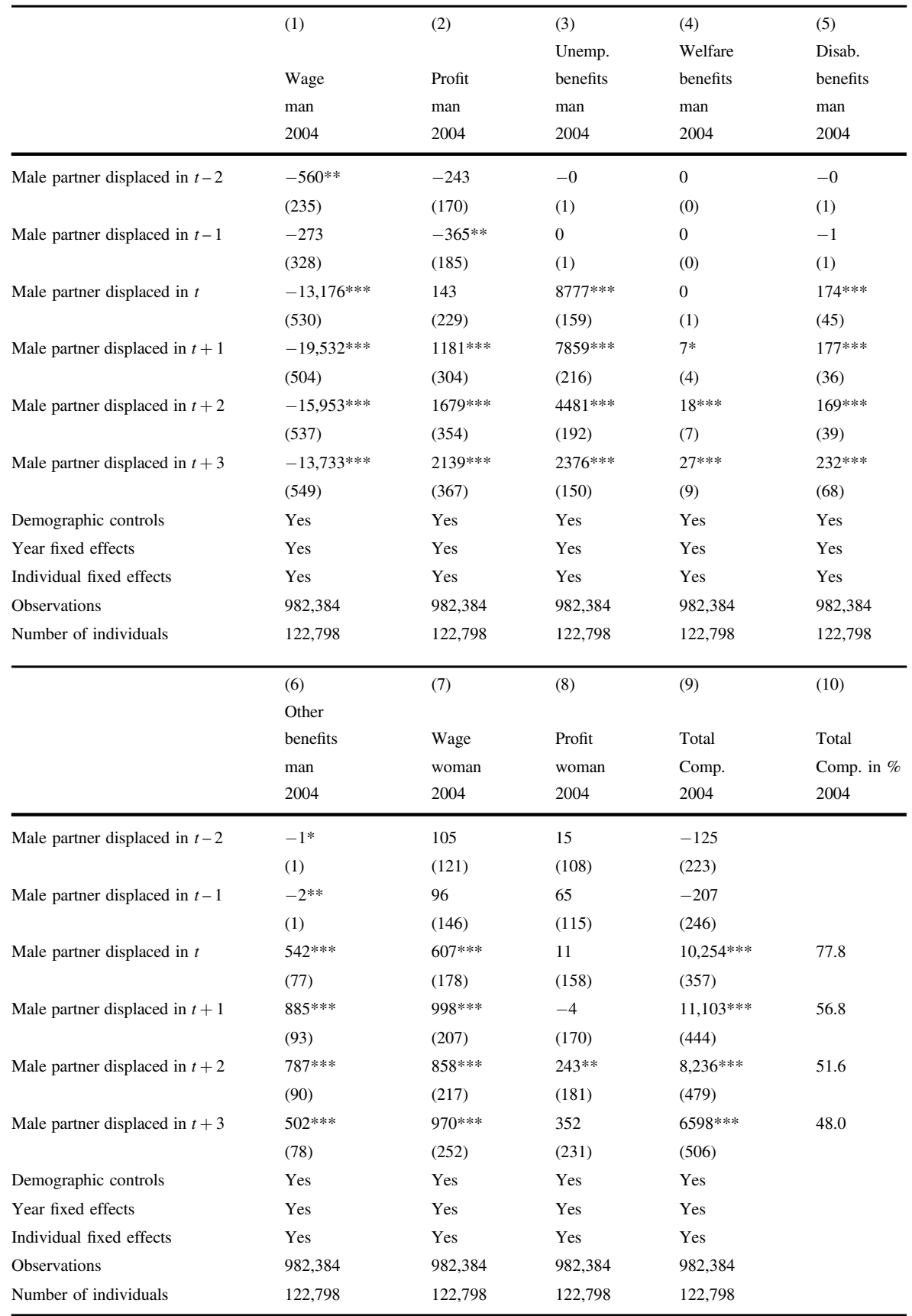

Standard errors in parentheses. Our sample consists of couples 25-55 years of age in the year before the unemployment shock. Furthermore, we select couples in which the husband has an annual income from work of at least 5000 euros in the four years before the treatment and with the husband not receiving income from UI, social assistance or other benefits in the pre-treatment period. All specifications include year dummies, time-varying demographic controls (age) and individual fixed effects.

*Denotes significance at the $10 \%$ level, $* *$ at the $5 \%$ level and *** at the $1 \%$ level 
Table 8 Effect of male partner becoming unemployed in 2008 on different income sources

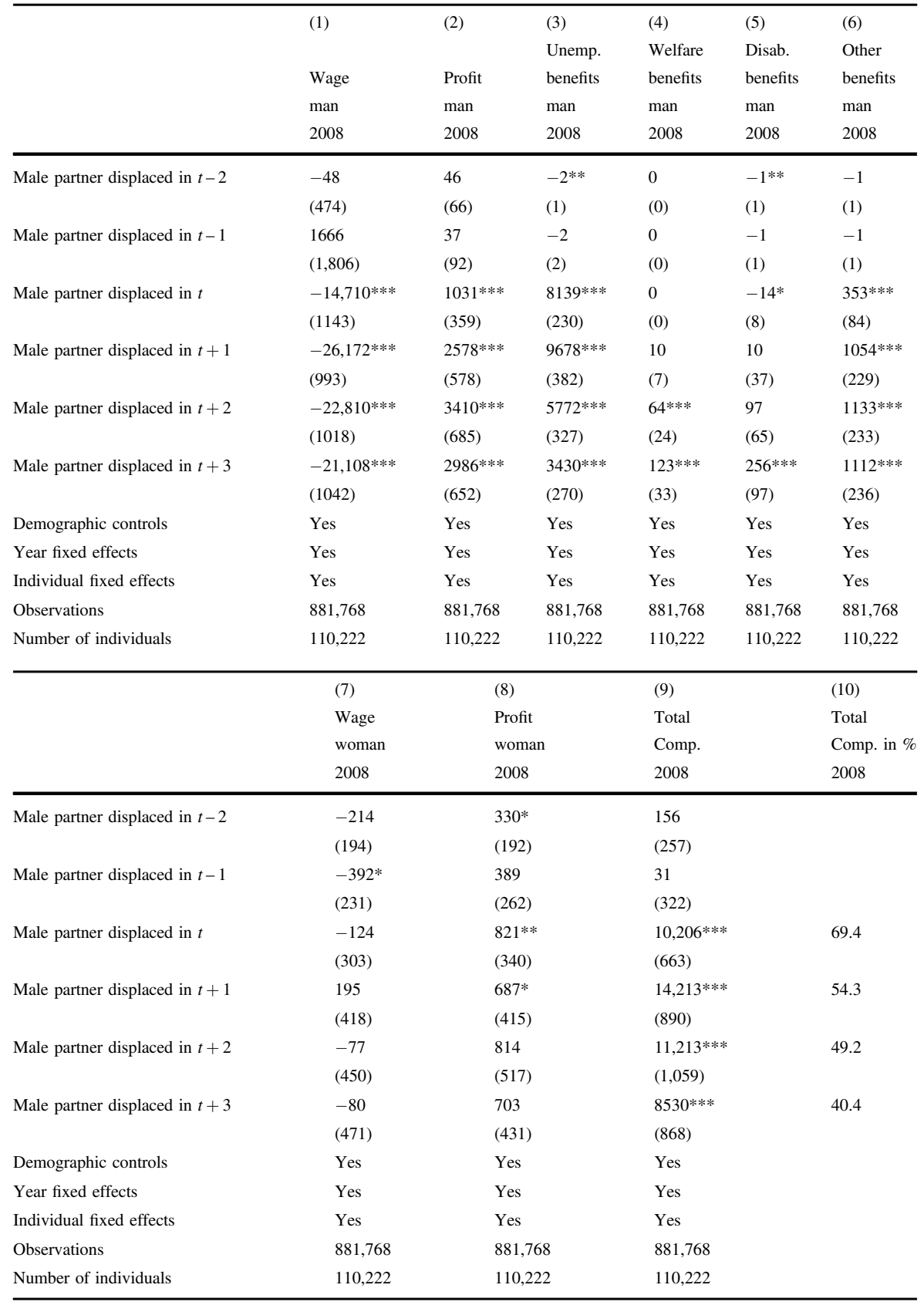

Standard errors in parentheses. Our sample consists of couples 25-55 years of age in the year before the unemployment shock. Furthermore, we select couples in which the husband has an annual income from work of at least 5000 euros in the four years before the treatment and with the husband not receiving income from UI, social assistance or other benefits in the pre-treatment period. All specifications include year dummies, time-varying demographic controls (age) and individual fixed effects.

*Denotes significance at the $10 \%$ level, $* *$ at the $5 \%$ level and $* * *$ at the $1 \%$ level 
Table 9 Effect of male partner becoming unemployed in 2012 on different income sources

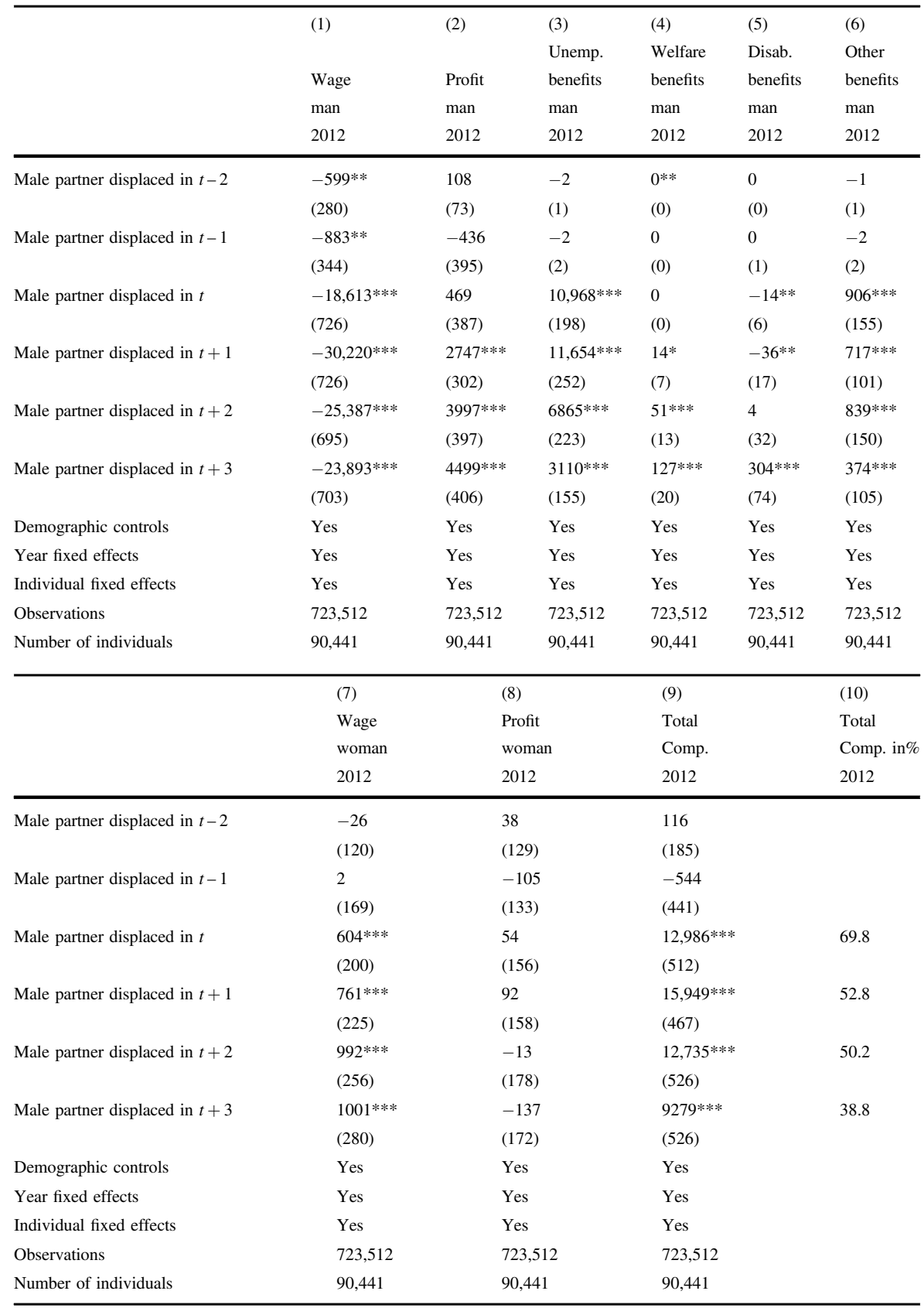

Standard errors in parentheses. Our sample consists of couples 25-55 years of age in the year before the unemployment shock. Furthermore, we select couples in which the husband has an annual income from work of at least 5000 euros in the four years before the treatment and with the husband not receiving income from UI, social assistance or other benefits in the pre-treatment period. All specifications include year dummies, time-varying demographic controls (age) and individual fixed effects.

*Denotes significance at the $10 \%$ level, $* *$ at the $5 \%$ level and *** at the $1 \%$ level 
of income, such as the AWE, and how much remains uncovered. For ease of exposition, we only report results for a limited number of representative reference years: 2004, 2008 and 2012; these are shown in Tables 7-9, respectively.

Table 7 shows the effect of a male worker entering UI on different income sources, for the treatment year 2004. Column (1) shows a negative effect on male partner's wage income of about 13 thousand euros in the year after becoming unemployed, which then decreases to less than 14 thousand euros three years after entering UI. The average income from self-employment for the worker increases up to about 2 thousand euros three years after entering UI (column (2)). UI benefits compensate somewhat less than 9 thousand euros of the wage loss in the year of the unemployment shock, but this drops to less than 2500 euros 3 years after the unemployment shock (column (3)). Treatment effects on income from welfare benefits, disability benefits and other benefits, which are relatively small, are given in columns (4), (5) and (6). The AWE that is channelled through wage and profit income is presented in columns (7) and (8), respectively. After three years, the AWE from wage income is almost 1000 euros and from profits it is about 350 euros. Finally, column (9) shows that the total amount of 'compensation' is about 10 thousand euros in year $t, 11$ thousand euros in year $t+1$ and about 6500 euros in $t+3$. This implies that about $78 \%$ of the income loss is compensated in the year of the unemployment shock, and subsequently decreases to $48 \%$ of the remaining wage income shock 3 years after entering UI. This decrease can largely be attributed to the drop in UI benefits. The AWE covers only $10 \%$ of the remaining wage income shock three years after entering UI.

Table 8 provides the results for couples where the male enters UI in 2008, the year the Great Recession started. The negative treatment effects on the wage income of the male are larger and more persistent than in 2004. The compensation from the UI of the male partner increases as well, but decreases as a percentage of the wage income shock. The compensation from the profit income from the male partners increases, but there is no significant AWE from wage income of the female. The total compensated amount is higher in 2008 than in 2004, but is a smaller as a share of the (larger) loss in wage income of the male. Finally, Table 9 gives the results for couples where the male enters UI in 2012, which was the second period of the Great Recession ((the 'double dip' of the eurocrisis) in the Netherlands. The loss in wage income of the male is clearly larger than for 2008, but the treatment effect on male partner's profits is also larger than in the earlier years, rising to about 4500 euros three years after entering UI. It thus seems that the extent to which self-employment contributes to compensating male partner's loss in wages has increased over time.

\section{Discussion and conclusion}

Our analysis shows that the size of the AWE is small and similar to earlier analyses in this field of research. With treatment and control samples of male workers with fairly stable wage earnings, the large and persistent income shock of about 25 thousand euros one year after becoming unemployed (about $50 \%$ of previous wage earnings) leads to the AWE from the partners' wages between 500 and 1000 euros 
(2-5\%). In terms of income compensation, this effect is small compared to the compensation coming from UI benefits.

At the same time, the use of a long time period and a rich set of outcome variables does provide us with new insights on changes in the AWE over time. Specifically, we are able to analyze changes in the AWE that most likely are linked to business cycle effects. Most notably, the AWE drops considerably in size and becomes insignificant in the first years of the Great Recession (2008-2009). After that, the AWE resurfaces to levels that are comparable in size to the years before 2008. Consistent with Halla et al. (2020), it is likely that depressed labour demand limited AWE on realized income increases-see also Maloney (1987, 1991), Juhn \& Potter (2007) and Bryan \& Longhi (2018).

Our analysis also sheds new light on the interrelationship between the AWE and structural changes in labour market characteristics. In the years in our sample, we witness a steep increase in the labour force participation of women in the Netherlands. Since the majority of these female workers work part-time employment, one would expect an increasing role for the intensive margin AWE and a decreasing role for extensive margin AWE. While the AWE at the extensive margin indeed decreases over time, increases in intensive margin effects are statistically significant only and in the most recent years in our sample. Specifically, intensive margin effects seem almost absent between 2008 and 2010, which points at the importance of firm-side restrictions in this period.

Given the increase in the share of self-employed workers in the Netherlands, from $15 \%$ in 2000 to about $20 \%$ in 2015 , a final question we address is whether the 'insurance' through profit income from self-employment has gained in importance. We indeed find that the effect from this source of income has increased over time. In particular, profit income by the men three years after entering UI increases from about 2000 euros in 2004 to about 4500 euros in 2012. Hence, especially for the later years in our sample, one would miss an important part of dealing with job loss if one would ignore the effect from profit income.

Finally, it should be stressed that the effect on employment and income does not provide us with (direct) evidence on labour supply or job search effort. Future research is needed to study if the AWE is small because of small labour supply responses or because increases in labour supply do not translate into increases in employment (Juhn \& Potter, 2007; Bryan \& Longhi, 2018). The latter explanation may be particularly relevant during an economic downturn. Studying both labour supply responses and employment responses in one study could resolve that some studies (e.g., Bredtmann et al., 2018) find the AWE to be larger when unemployment is higher and others find the AWE to be smaller when unemployment is higher (e.g., Halla et al., 2020). Future research could also look at the effect of entering UI on broader outcome measures, like the stability of relations and fertility (as in Halla et al., 2020) and other outcomes like health, happiness and well-being (as in Nikolova, 2019).

Acknowledgements We are grateful for comments and suggestions by the editor Sonia Oreffice, the editor-in-chief Shoshana Grossbard, two anonymous referees, Wolter Hassink and seminar and conference participants at CPB Netherlands Bureau for Economic Policy Analysis, the IIPF 2018 conference in Tampere and the EALE 2019 conference in Uppsala. The remaining errors are our own. 


\section{Compliance with ethical standards}

Conflict of interest The authors declare no competing interests.

Publisher's note Springer Nature remains neutral with regard to jurisdictional claims in published maps and institutional affiliations.

Open Access This article is licensed under a Creative Commons Attribution 4.0 International License, which permits use, sharing, adaptation, distribution and reproduction in any medium or format, as long as you give appropriate credit to the original author(s) and the source, provide a link to the Creative Commons license, and indicate if changes were made. The images or other third party material in this article are included in the article's Creative Commons license, unless indicated otherwise in a credit line to the material. If material is not included in the article's Creative Commons license and your intended use is not permitted by statutory regulation or exceeds the permitted use, you will need to obtain permission directly from the copyright holder. To view a copy of this license, visit http://creativecommons.org/licenses/by/4.0/.

\section{References}

Ayhan, S. H. (2018). Married women's added worker effect during the 2008 economic crisis-The case of Turkey. Review of Economics of the Household, 16, 767-790.

Bredtmann, J., Otten, S., \& Rulff, C. (2018). Husband's unemployment and wife's labor supply: The added worker effect across Europe. Industrial and Labor Relations Review, 71, 1201-1231.

Bryan, M., \& Longhi, S. (2018). Couples' labour supply responses to job loss: Growth and recession compared. The Manchester School, 86, 333-357.

Deelen, A., de Graaf-Zijl, M., \& van den Berge, W. (2018). Labour market effects of job displacement for prime-age and older workers. IZA Journal of Labor Economics, 7, 3.

Ghignoni, E., \& Verashchagina, A. (2016). Added worker effect during the Great Recession: Evidence from Italy. International Journal of Manpower, 37, 1264-1285.

Halla, M., Schmieder, J., \& Weber, A. (2020). Job displacement, family dynamics and spousal labor supply. American Economic Journal: Applied Economics, 12, 253-287.

Hardoy, I., \& Schøne, P. (2014). Displacement and household adaptation: Insured by the spouse or the state? Journal of Population Economics, 27, 683-703.

Heckman, J. J., \& MaCurdy, T. (1980). A life cycle model of female labour supply. The Review of Economic Studies, 47, 47-74.

Juhn, C., \& Potter, S. (2007). Is there still an added-worker effect? Staff Report 310, Federal Reserve Bank of New York, New York.

Maloney, T. (1987). Employment constraints and the labor supply of married women: A reexamination of the added-worker effect. Journal of Human Resources, 22, 51-61.

Maloney, T. (1991). Unobserved variables and the elusive added-worker effect. Economica, 58, $173-187$.

Mattingly, M. J., \& Smith, K. E. (2010). Changes in wives' employment when husbands stop working: A recession-prosperity comparison. Family Relations, 59, 343-357.

Meekes, J., \& Hassink, W. H. (2019). The role of the housing market in workers' resilience to job displacement after firm bankruptcy. Journal of Urban Economics, 109, 41-65.

Nikolova, M., \& Ayhan, S. (2019). Your spouse is fired! How much do you care? Journal of Population Economics, 32, 799-844.

OECD (2018). OECD Economic Surveys: Netherlands 2018. OECD Publishing, Paris.

Parker, S. W., \& Skoufias, E. (2004). The added-worker effect over the business cycle: Evidence from urban Mexico. Applied Economics Letters, 11, 625-630.

Starr, M. A. (2014). Gender, added-worker effects, and the 2007-2009 recession: Looking within the household. Review of Economics of the Household, 12, 209-235. 